\title{
Glagoljaštvo prvih desetljeća 20. stoljeća u Nižićevim bilješkama
}

\begin{abstract}
U radu se donose bilješke o glagoljaštvu o. Ante Nižića, popa glagoljaša Zadarske nadbiskupije, koji je 1920. zbog talijanske okupacije rodnoga zavičaja i glagoljaških duhovnih poticaja postao franjevac trećoredac glagoljaš. U trećoredskom je samostanu na Ksaveru u Zagrebu pronađeno pet njegovih bilježnica s raznoraznim bilješkama, koje prilično dobro otkrivaju njega i njegovo vrijeme. One svjedoče da je kao pop glagoljaš ravnokotarskih i otočnih župa neumorno radio na podizanju obrazovanja, kulture i gospodarstva seoskoga stanovništva, promičući hrvatske nacionalne ideje, a da je s istim žarom nastavio kao redovnik, promičući glagoljašku duhovnost, franjevački svjetovni red, Počasnu stražu Presvetoga Srca Isusova i izdanja Hrvatskoga književnoga društva sv. Jeronima do 1935., kada je otišao u Sjedinjene Američke Države. Na poseban nam način otkrivaju njegovu privrženost glagoljaštvu kao vlastitom duhovnom izrazu, koje bogoslužjem na staroslavenskom jeziku pruža dodatnu dimenziju Katoličkoj crkvi, a pred talijanskim imperijalizmom i okupacijom hrvatskih krajeva pruža nacionalnu zaštitu.
\end{abstract}

\section{I.}

Glagoljaštvo je duboko ukorijenjena jezičnoliturgijska, kulturnopovijesna i nacionalnointegracijska odrednica u Hrvata, koju se pred katoličkim univerzalizmom često stavljalo u izdvojen i rubni položaj, očitovan u stalnom naporu glagoljaškoga svećenstva da opravda svoje glagoljanje. Povijest, pak, uči da je bogoslužje na staroslavenskom jeziku po zapadnom obredu, odnosno rimsko-slavenski obred službeno stekao katolički legitimitet u 13. stoljeću, da se takvo bogoslužje teško probijalo kroz povijesni put zbog toga što je iznimka u rimokatoličanstvu te da je bilo pred zamiranjem nakon zatvaranja dalmatinskih glagoljaških sjemeništa i neprepoznavanja staroslavenskoga kao liturgijskoga i kulturološkoga fenomena

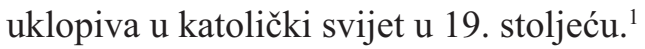

Do zaokreta dolazi posredno s novim katoličkim pogledom prema Istoku za pontifikata Leona XIII. (1878. - 1903.). Slavenima je on simbolično upućen enciklikom Grande munus iz 1880., kada su Sveta braća Ćiril i Metod ekvipolentnom

1 RELJANOVIĆ 2001: 357; VELČIĆ 2015: 76. 
kanonizacijom svečano proglašeni svecima Katoličke crkve te su postali trajnim zalogom približavanju i boljim odnosima s istočnim kršćanima. ${ }^{2}$ Papa je dobio poticaje od katolika srednjoeuropskih slavenskih zemalja, koji su kroz ćirilometodski pokret, nadahnut djelom rečene Svete braće, radili na jedinstvu cijele Crkve. Time je glagoljaštvu, kojemu se kroz tadašnju znanstvenu literaturu dokazalo da je baštinik ćirilometodske tradicije, ponovno omogućen jedinstven položaj i samostalan razvoj u Katoličkoj crkvi, a nov je život udahnut i hrvatskoglagoljskoj baštini, koja je zbog viših i širih interesa Rimske kurije bila potpuno zapostavljena rusifikacijom hrvatskoglagoljskih liturgijskih knjiga u 17. i 18. stoljeću.

Hrvatskomu se svećenstvu Kraljevine Dalmacije i Austrijskoga primorja (Markgrofovija Istra, Gorica i Trst) tako otvorila perspektiva obnove liturgijskoga pastorala u duhu izvornoga glagoljaštva s osloncem na hrvatskoglagoljsku baštinu. U pripremi takvih bogoslužnih činova i tekstova gotovo je sav posao na se preuzeo svećenik glagoljaš Dragutin Parčić (1832. - 1902.), koji je unatoč silnim pritiscima i stalnim osporavanjima, ali i uz Strossmayerov blagoslov, 1893. u Rimu uspio tiskati novi glagoljski Rimbski misalb slavěnbskimb ezikomb prěsv. g. n. Urbana papi VIII povelěniemb izdanb na hrvatskome novocrkvenoslavenskom i latinični Rimski ritual (obrednik) izdan po zapoviedi Sv. Otca Pape Pavla V a pomnožan $i$ poizpravljen Benediktom XIV. na suvremenom hrvatskom jeziku. ${ }^{3}$

Osim što su prekinule dotadašnje rusificiranje rimokatoličkih liturgijskih knjiga, te su knjige silno razbuktale glagoljaške osjećaje u hrvatskom svećenstvu, tako da je glagoljaštvo doskora počelo zahvaćati sav hrvatski nacionalni prostor. Istodobno broj glagoljaških župa i glagoljaških svećenika zbog raznih prepreka njihovih pastira i austrijskih vlasti nikada nije bio manji. Samo u Zadarskoj nadbiskupiji, povijesno najglagoljaškijoj u Katoličkoj crkvi, od 84 župe, koliko ih je ukupno bilo 1857., glagoljaških je bilo čak 46, sa 70 svećenika glagoljaša, a krajem 19. stoljeća glagoljalo se samo u nekoliko mjesta, isključivo zahvaljujući upornosti njihovih župnika, koji nisu podlijegali višim pritiscima. ${ }^{4}$

Glagoljaštvo iliti glagoljica (glagolica), koja je bila terminus technicus za staroslavenski jezik u rimokatoličkom bogoslužju tijekom druge polovine 19. i

2 ŠULJAK 1994: 290; RELJANOVIĆ 2001: 360-361; VUKŠIĆ 2002: 82; BANAC 2013: 34-35. Mjesne su, pak, pravoslavne crkve s budućega jugoslavenskog teritorija bile krajnje sumnjičave prema rečenoj enciklici i drugim pokušajima ekumenskoga dijaloga, smatrajući ih samo novim oblicima katoličkoga unijaćenja (usp. MATAUŠIĆ 2002: 47; VUKŠIĆ 2002: 89-92).

3 SOLDO 1990: 172-173, 181-182. Rim je službeno još 1868. dopustio izradu novoga glagoljskog misala (BANAC 2013: 34). Zanimljivo je da su neki liturgijski stručnjaci u pripremnoj liturgijskoj komisiji Drugoga vatikanskog koncila, prema riječima dr. Dragutina Kniewalda, bili gotovo zaprepašteni nad činjenicom da Hrvati već stoljećima upotrebljavaju obrednike na narodnom jeziku jer su $i$ latinski, a s njime i staroslavenski, potisnuti tako iz redovite liturgijske upotrebe (TANDARIĆ 1973: 205).

4 DIKLIĆ 2002: 135. 
prve polovine 20. stoljeća ${ }^{5}$, postaje važna crkvena i politička tema nakon što su katolici Barske nadbiskupije 1886./1887. blagoslovom crnogorskoga dvora stekli papinski privilegij o mogućnosti bogoslužja i na staroslavenskom jeziku. ${ }^{6}$ Naime, austrijske su vlasti u rimsko-slavenskom obredu otada počele gledati opasnost $\mathrm{u}$ međupovezivanju ne samo južnoslavenskih naroda, već i moguću vezu njegovih poklonika s Rusijom, koja je Austriji čak i na Jadranu bila geopolitički takmac. Vrhunac pritiska vlasti na mjesne biskupe, a time i na Svetu Stolicu dogodio se 5. kolovoza 1898., kada je blagoslovom bečke diplomacije iz Rima upućen dekret o upotrebi staroslavenskoga jezika nadbiskupima, biskupima i ordinarijatima Zadarske, Goričke i Zagrebačke nadbiskupije, kojim je zabranjeno mijenjati bogoslužni jezik i naređeno utvrđivanje uporabne tradicije bogoslužnoga jezika u svakom pojedinačnom slučaju unazad 30 godina. ${ }^{7}$ Mjesec je dana kasnije biskup Giovanni Battista Flapp (1882. - 1912.) na temelju toga dekreta svoju Porečku i Pulsku biskupiju proglasio dijecezom bez ijedne glagoljaške župe. ${ }^{8} \mathrm{Na}$ tom je tragu 7. ožujka 1899. i u Zadarskoj nadbiskupiji potpuno zabranio glagoljanje njezin nadbiskup Grgur Rajčević (1891. - 1898.), naloživši da se potkažu svećenici koji bi se o nj ogriješili. ${ }^{9}$

Upravo je ta odluka, prema svjedočanstvu istaknutoga pravaškog političara i gorljivoga svećenika glagoljaša don Ive Prodana (1852. - 1933.), užegla vulkan izpod našega naroda i svećenstva da pod zakonitim protumjerama u cijeloj Kraljevini Dalmaciji razvije snažan pokret za očuvanje glagoljice i prava hrvatskoga naroda na njezinu neograničenu uporabu u bogoslužju. ${ }^{10}$ Budući da su južnodalmatinski biskupi, dubrovački Josip Marčelić (1894. - 1928.) i kotorski Frano Ucellini (1895. - 1937.), odlučno stali uz slobodnu uporabu glagoljice u Crkvi ${ }^{11}$, Sveta je Stolica, suočena s proturječnostima, u rujnu 1899. ovlastila vrhbosanskoga nadbiskupa Josipa Stadlera (1881. - 1918.), koji je na štrosmajerovskom tragu odnedavna zagovarao staroslavensko bogoslužje u Crkvi ${ }^{12}$, da diskretno ispita pitanje glagoljaštva u Kraljevini Dalmaciji i Austrijskom primorju te da o tome podnese izvješće Svetoj Stolici. ${ }^{13}$ On je o tome odmah obavijestio dubrovačkoga biskupa Josipa Marčelića, splitskoga svećenika don Franu Bulića (1846. - 1934.)

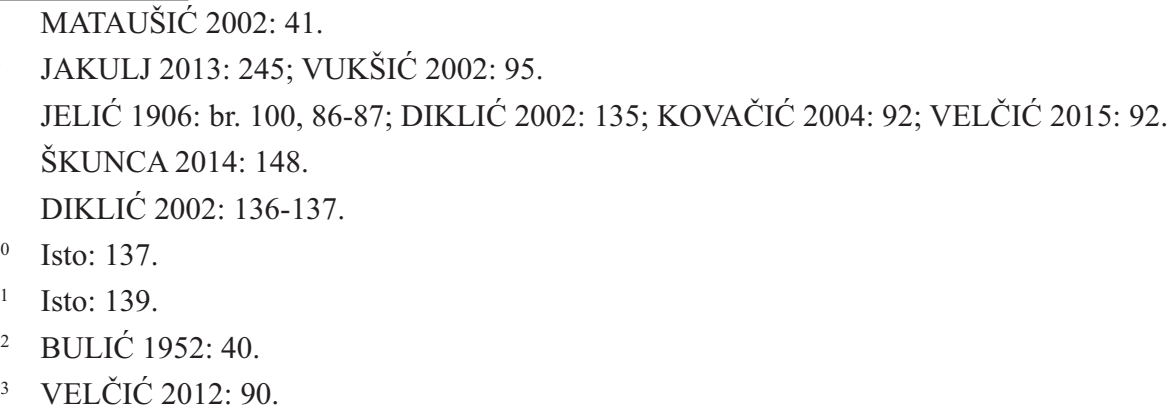


i krčkoga biskupa Antuna Mahnića (1896. - 1920.), zatraživši preko svojih povjerenika da prikupe tražene odgovore od svećenika. Podaci koji su u tajnosti na raznorazne načine od žandarmerije pristizali od Kotora do Trsta poslužili su za sastavljanje Spomenice, koju su u ožujku 1900. s potpisima 535 svećenika uručili vrhbosanski nadbiskup Josip Štadler, don Frane Bulić i krčki kanonik Franjo Volarić (1851. - 1908.), prema Bulićevu svjedočanstvu tadašnji triumviri pro defenda lingua veteroslavica ${ }^{14}$, državnomu tajniku Svete Stolice u Rimu. ${ }^{15}$

Na temelju ukaza Spomenice, ali i dospjela utoka svećenstva i puka Zadarske nadbiskupije, iza kojeg je stajao don Ivo Prodan, Zbor za svete obrede 22. kolovoza 1900. odobrio je mogućnost bogoslužja na staroslavenskom jeziku u crkvama Zadarske nadbiskupije. Premda se pozvao na svoju raniju odluku o dokazima glagoljanja unazad 30 godina u crkvi, ovaj se put tražio samo dokaz o glagoljanju iz župne prošlosti. ${ }^{16}$ Glagoljaštvo se istodobno slilo u politički program Prodanove Čiste stranke prava, koju je, uz doista rijetke iznimke, podržavalo sve hrvatsko svećenstvo u Dalmaciji. ${ }^{17}$ Boreći se za glagoljicu, tu najveću kulturnu i duhovnu baštinu hrvatskoga naroda, dalmatinski su pravaši bili uvjereni da se bore za hrvatsku državu, za njezino jedinstvo, opstojnost $i$ samostalnost protiv vjekovnih neprijatelja hrvatstva i Hrvatske. ${ }^{18}$

Stoga je bilo mnogo napada na glagoljicu. Jedan anonimni, iza kojeg je vjerojatno stajao porečki i pulski biskup Giovanni Battista Flapp, 1896. spriječio je distribuciju novoga popravljenog izdanja glagoljskoga misala i latiničnoga obrednika već u Rimu zbog tobože mnogih antidogmatičkih i nedostojnih izraza o Blaženoj Djevici Mariji i Presvetom Trojstvu. ${ }^{19}$ Najradikalniji su, pokušavajući na svakojake načine osporiti legitimnost i opravdanost glagoljaštva u Katoličkoj crkvi, išli čak dotle da su rimsko-slavenski obred smatrali raskolničkom misom na ciganskom jeziku (lingua di zingari). ${ }^{20}$ Time se dodatno rasplamsavala već bukteća vatra osobito loših talijansko-hrvatskih odnosa, koju su austrijske vlasti Kraljevine Dalmacije raspirivale ustrajnim davanjem prednosti talijanskomu pred hrvatskim jezikom u najvažnijim područjima javnoga i kulturnoga života, pravdajući svoja načela i odluke civilizacijskim dosezima talijanske pred hrvatskom i slavenskom kulturom. S druge pak strane, krčki biskup Antun Mahnić, utemeljitelj Hrvatskoga katoličkog pokreta, obraćajući se svomu svećenstvu, pisao je o

\footnotetext{
14 BULIĆ 1952: 41.

15 VELČIĆ 2012: 90.

16 DIKLIĆ 2002: 141.

17 MOSCATELLO 2014: 170.

18 DIKLIĆ 2002: 141.

19 BOLONIĆ 1968: 283; SOLDO 1990: 184.

20 VELČIĆ 2015: 95.
} 
staroslavenskome kao o svetinji u svetim obredima jer se $u$ tom jeziku prikazuje sveta misa i svete tajne. ${ }^{21}$

Tako je glagoljaštvo početkom 20. stoljeća bilo važna hrvatska nacionalnointegracijska odrednica. Njegova je kulturna i duhovna baština poticala svijest o pripadnosti hrvatskoj naciji i pružala zaštitu od autonomaško-iredentističkih aspiracija, koje su na identitetsko i kulturno graničnim područjima Kraljevine Dalmacije i Austrijskoga primorja sve više dolazile do izražaja.

Neprijatelja glagoljice, piše u svojim Zapisima hvarski svećenik Nikola Moscatello (1885. - 1961.), koji je bio dugogodišnji savjetnik jugoslavenskoga poslanstva u međuratnom razdoblju pri Svetoj Stolici, nestalo je s propašću Austro-Ugarske, dodavši da je baš u vezi s time jenjao i interes za glagoljicu u našoj javnosti, koja se sada našla pred novim političkim i narodnim problemima, hitnijim od pitanja upotrebe staroslavenskog jezika u liturgiji. ${ }^{22}$ Drugim riječima, glagoljica se ispolitizirala do te mjere da je mnogima postala paradigma jugoslavenstva, činjenicom otpora samomu Rimu i sredstvom duhovnoga odvajanja od samoga Rima. O tome nekom drugom prigodom jer te konstatacije izlaze iz okvira ovoga rada. Glagoljaška tradicija hrvatskoga sela sigurno počinje zamirati nakon 1918. kada pitanje staroslavenskoga jezika u rimokatoličkom bogoslužju postaje predmetom visoke crkvene i državne politike, što se osobito vidjelo u međudržavnim odnosima između Svete Stolice i prve Jugoslavije, kada se neprihvaćenim konkordatom umjesto pojedinačnih dragovoljnih pristanaka na staroslavensko liturgijsko ophođenje zahtijevalo bezuvjetno uvođenje staroslavenskoga bogoslužja u sve rimokatoličke crkve s jugoslavenskoga prostora. ${ }^{23}$

II.

Na prijelazu stoljeća, kada su se svjetonazorski stavovi i politički odnosi u Dalmaciji mjerili preko glagoljaštva, u seoskim je župama Zadarske nadbiskupije djelovao mladi pop Ante Nižić (18. V. 1873. - 4. III. 1963.). Od zaređenja 1896. pa do talijanske okupacije zadarskoga područja bio je kapelan, ekskurent, župnik u rodnom Preku, Banju, Pašmanu, Turnju, Korlatu, Nadinu, Lukoranu, Bokanjcu i Zadru (N: 223-226; L: 526, 197). Ne mireći se s talijanskom okupacijom svoga zavičaja, iz hrvatskih je nacionalnih pobuda i glagoljaških duhovnih poticaja pristupio franjevačkoj trećoredskoj samostanskoj zajednici. Prema svjedočanstvu njegova suvremenika fra Kerubina Sišula (1892. - 1981.), u franjevce ga je trećorece glagoljaše privukla glagoljica, a u franjevačkim je trećoredskim samostanima

21 BRATULIĆ 2015: 21.

22 MOSCATELLO 2014: 147.

23 NOVAK 1948: 263-278; MOSCATELLO 2014: 149-150. 
još uvijek bio živ u njihovo vrijeme. ${ }^{24}$ Njegov politički i svećenički uzor don Ivo Prodan pod pritiskom talijanskih iredentista i fašista također se morao maknuti iz Zadra, koji je dalmatinskim Hrvatima zbog svih državnih, vojnih i građanskih institucija u gradu bio kao mali Bec ${ }^{25}$ te se sa svojom Katoličkom hrvatskom tiskarom sklonio u Nižićevo rodno Preko na Ugljanu, koji je Rapallskim ugovorom ostao u Kraljevini SHS. ${ }^{26}$

Nižić je kao pop glagoljaš predano radio u podizanju obrazovanja, kulture i gospodarstva svojih ravnokotarskih i otočkih župa, a kao franjevac trećoredac glagoljaš osobito je promicao glagoljašku tradiciju, Počasnu stražu Presvetoga Srca Isusova i franjevački svjetovni red. Od 1935. pa do smrti 1963. pastoralnom je službom bio vezan za hrvatske katoličke misije u SAD-u. Među najzaslužnijima je za otvaranje pučke škole u Banju i Nadinu (N: 77), uspostavu brzojavne veze i ureda u Nadinu ${ }^{27}$, pokretanje seoske zadruge i blagajne u Nadinu (N: 52-54) ${ }^{28}$, utemeljenje Zaklade za odgoj i školovanje mladeži otoka Ugljana sa sjedištem u Preku (N: 147-155, L: 310-311), utemeljenje Zaklade don Ante Nižića za školovanje sjemeništaraca iz župa njegova pastoralnoga djelovanja (L: 196-197), otvaranje podružnica Književnoga društva sv. Jeronima u Nadinu i Preku (N: 30$)^{29}$, župne knjižnice u Nadinu i Lukoranu $^{30}$, pokretanje inicijative za isušivanje Nadinskoga blata $(\mathrm{N}: 185,211)$ itd.

24 SIŠUL 1963: 23.

25 MOSCATELLO 2014: 23.

26 DIKLIĆ 2002: 120-121. U svom siromaštvu, bolesti i starosti na Ugljanu, don Ivo Prodan nastavio je surađivati i prijateljevati s franjevcima trećorecima glagoljašima s obližnjega Školjića, koji će 1930. ponosno kupiti njegovu tiskaru, a on će 1933. nakon smrti biti pokopan na njihovu samostanskom groblju.

27 Opravdanje uspostavi brzojavne veze 1908. i ureda 1912. u Nadinu išlo je k vlastima preko Nižićeva prijatelja i pravaškoga zastupnika don Ive Prodana, a temeljilo se na činjenici da se mjesto nalazi uz carsku cestu, pokraj koje je već bila provedena brzojavna žica (N: 28, 76-79), i da je trokratna tjedna pošta prolazila kroz Nadin još od 1893. (N: 30). Prvi brzojav upućen iz Nadina bio je upravo Nižićev, i to bratu u Preko (N: 183).

28 Više je puta zapisao da se nalazio s pravaškim zastupnikom don Ivom Prodanom, kojem je iznosio razne ideje. Tako mu je jednom prenio, na tragu postojanja Hrvatske poljodjelske banke, koja iz političkih razloga u Dalmaciji nije uspjela otvoriti ispostave (usp. KOLAR 2002: 195209), da bi se u Zadru trebala otvoriti Hrvatska pučka štedionica, koja bi bila neovisna banka i time praktično sredstvo za provođenje hrvatskih ideja po dalmatinskim mjestima i koja bi riješila ovisnost od zaduživanja kod talijana (N: 31-32). Samu bi stvar, nadalje kaže, trebalo dobro pripremiti, obavijestiti pučanstvo lecima, utvrđenim protokolom otvarati štedionice po dalmatinskim selima te završava da bi time izazvali pravi požar prot talijanštinom grada Zadra i da bi time svi naši protivnici bili pobijeđeni (N: 32).

29 U Preku je osnovao podružnicu 1909., skupa s bratom Matom, koji je nekoliko godina ranije kratko bio u Americi (N: 202). Nastojao je da svaka kuća u Preku i obližnjim mjestima ima redovita svetojeronimska izdanja (SIŠUL 1963: 24).

30 Knjižnica u Nadinu, osnovana 1906. pod mahnićevskim geslom Za vjeru i dom, imala je osamdesetak knjiga, uglavnom nabožnoga i poučnoga sadržaja već rečenoga Društva sv. Jeronima iz Zagreba (N: 85). 
Svojim je principijelnim djelovanjem izazivao divljenje, ali i otpor jer je dosta radio na svoju ruku. Tako je u Nadinu 1909., ukinuvši drevni običaj obilaska cijeloga mjesta Križevskom procesijom na Markovo, koji je postojao od 1793. (N: 68), uveo ophod samo oko crkve zbog navodno nedoličnoga ponašanja pojedinaca i njihova zadiranja u crkvene propise (N: 69). Nisu ga tada omele ni prijetnje seoskoga glavara i njegovih istomišljenika, kojima je u propovijedi uputio odrješitu poruku: Kakav pop, takav puk, kakav puk, takav pop. Najveće prokletstvo za narodje imati hrdjave popove ili biti bez njih. Čuvajte se, da ne ostanete bez popa, koga će te tada tekar znati cieniti. Upamtite ovo par prijateljskih rieči, usadite u srce. Hvaljen Isus! (N: 20). Neke je običaje oko Križovske procesije ukinuo i u Lukoranu 1914., kada je kolovođa pobune bio remeta Mate Martinov (L: 244).

Jedna od Nižićevih inicijativa, koja se dočekivala oduševljeno ili s velikim otporom, bilo je izjašnjavanje za hrvatsku trobojnicu, koju bi za svoga župnikovanja uvijek držao izvješenu na pročelju župne crkve ili zvoniku (N: 43, 54; L: 548). Dok se hrvatski barjak vijorio bez ičijega prigovora u Nadinu i Korlatu (N: 210), a zavijorio se čak i u Kuli Atlagića, gdje su bile tek četiri katoličke obitelji (N: 45), u Lukoranu je njegovo nastojanje da stavi hrvatsku trobojnicu na crkvu dočekano s velikim otporom. Čak je od jeseni 1911., pa do ulaska Italije u Prvi svjetski rat zastava u mjestu bila prijeporni politički objekt. Tako mu je u srpnju 1913. stara Tomica dobacila da su svi diavli u vašoj trobojnici (N: 34), a u svibnju 1912. presjekli su je neki Lukoranci, predvođeni budućim glavarom Lukom Perom (L: 548). Taj događaj Nižića nije nimalo pokolebao te je još više prionuo nacionalnomu osvješćivanju u Lukoranu preko određenih manifestacija. Silno se npr. veselio kada je u kolovozu 1913. Lovre Bekafigo izvjesio hrvatsku trobojnicu na svoju kuću (L: 38).

Početkom rata politički su se odnosi između župnika Nižića i Lukoranaca izgladili preko noći. Tako se u lipnju 1916. već spomenuti Mate Martinov župniku Nižiću javlja pismom uime jedanaestorice Lukoranaca, koji su kao pripadnici 22. domobranske pukovnije prije odlaska na bojište bili u Livnu (L: 248). Naglasili su da njihova pukovnija sve svoje pobjede protiv Italije prinosi Čudotvornoj Gospi Sinjskoj i da su u Livno stigli s čak 4 hrvatske trobojnice, na koje ih je on kao njihov župnik ustrajno upinjao. Matino pismo, pročitano sljedeće nedjelje s oltara, završava uputom: Širite viru Isusovu u našem narodu i hrvatski jezik učite našu dicu, biće Vam plaćeno od Gospodina i pjevajte s našom djecom svake nedilje 'Do nebesa nek se ori', jer neće se više usuditi u selu reći niko da je tolomaš ili da je talijanac, jadna mu je majka ako se živi povratimo. Pozdravljamo naše obitelji, nek stoje veselo i uviek idu svetoj misi i mole Boga da padne Italija (L: 248). Nakon toga, župnik je od svojih župljana zatražio da za hrvatske vojnike svakodnevno mole krunicu, a vojnicima je uputio poruku da se drže Boga i svoga hrvatskoga barjaka pod kojim vojujete (L: 248). Sličnim se sadržajem dopisnicom obratio lukoranskomu glavaru Luki Peri, koji se u kolovozu 1916. nalazio u Sunji: Pod 
hrvatskom našoj trobojnicom Vi marširate i spremate se da se ogledate talijanskim izdajnikom, a mi svi ovdje pod hrvatskom trobojnicom hranimo naš hrvatski jezik $i$ Vašu milu djecu da brane liticu i kamenje rodnoga Vam žala. Jezik matera naših, izvezen je pod našom hrvatskom trobojnicom, koji imade biti gospodaricom i kraljicom vašega i našega Lukorana (L: 290). S njime se pomirio početkom rata, a Filip Sikirić, vrativši se u listopadu 1915. s bojišta doma, župniku je nakon sv. mise rekao kako ga je rat naučio da je sve istina što nas uči sveta mati Crkva i kako mu je Luka Pera rekao sto puta da, vrati li se se živ kući, da će izvjesiti hrvatsku trobojnicu u selu, tekar sada je razumio da je župnik don Nižić imao pravo kad se je za istu borio i sve nam je istinu govorio. Talijanci više nemaju glasa u Lukoranu niti na ikojemu izboru (L: 392-393).

Da je Prvi svjetski rat dovršio hrvatsku nacionalnu osviještenost malih ljudi ondje gdje se hrvatski doticao s drugim jezicima i kulturama upravo svjedoči primjer Luke Pere. Dok je još u svibnju 1912. bio kolovođom trganja hrvatske trobojnice u Lukoranu, upravo je on 3. studenoga 1918. javno izvjesio hrvatsku trobojnicu ne u rodnom mjestu, već u samom Zadru, čime je potaknuo nadbiskupa Vicka Pulišića da u strahu od talijanskih simpatizera razvije talijansku trobojnicu na katedralu sv. Stošije (L: 548). Zanimljivo je kako je taj nadbiskupov čin bio okidač don Anti Nižiću, don Ivi Blasiću i don Roku Ušlju da su odlučili infacti, bez vike i buke, dne 10. 11. 1918. uzpostaviti glagolicu i sa strane župnika pa puklo kud puklo, odnosno da su u svojim bogoslužbama potpuno prešli na rimskoslavenski obred (L: 548), a samomu Nižiću da ubrza odluku o napuštaju svoje svećeničke službe u Zadarskoj nadbiskupiji i da postane redovnik u trećoredskoj samostanskoj zajednici.

Svugdje gdje je djelovao Nižić je dosta radio s djecom jer sa starima ne može se računati, a s djecom treba graditi novo selo (N: 26). ${ }^{31} \mathrm{U}$ Nadinu ga je osobito opterećivala seoska blagajna, koju je pokrenuo 1905. jer mu je samo donosila probleme, objede, podmetanja i laži (N: 15-20, 52-54). Najčešće je bio u svađi sa svima onima koji su varali pri seoskoj blagajni (N: 53). Isto tako sa seoskim učiteljima najčešće nije bio $u$ dobrim odnosima. Tako mu se $u$ Nadinu učitelj Maričić čudom čudio zašto na vjeronaučnoj nastavi hoda po razredu i ne sjedi za stolom (N: 41), a učitelj Darrer, koji je bio Nižiću suprotne naprednjačke političke orijentacije, ogovarao ga je gdje god je stigao da tobože drži narod u sužanjstvu (N: 53, 75).

Nižića su se, prema svjedočanstvu Jele Vrsaljko, bojali više negoli žandara u Nadinu jer je svakoga svojim perom mogao dobiti na sudu (N: 192). Tako je u veljači 1915. dobio parnicu protiv države jer od 19. srpnja 1910., kada je službeno imenovan za župnika u Lukoranu, pa sve do 17. listopada 1913. uopće

31 Tako je 1909. doveo fotografa u Nadin kako bi fotografirao prvopričesnike (N: 45). Riječ je o prvoj fotografiji učinjenoj u tom mjestu. 
nije primao župničku plaću (L: 470). Razloge takvu propustu Nižić je pronašao u svojoj pravaškoj orijentaciji i hrvatskom domoljublju, koji su bili kočnicom u dobivanju župničke službe na rodnom otoku (N: 42-43, 139). ${ }^{32}$ Uzevši u obzir da je bilješke o tome ostavio u posebno emotivnom stanju, može se ipak reći da se u svojim političkim stavovima, djelovanju i svjetonazoru nije previše izdvajao od većine katoličkih svećenika u Dalmaciji, koji su se uglavnom držali Prodanova pravaškoga vjersko-političkoga programa i njegove neustrašive borbe pod geslom za Boga i Hrvatsku, suprotstavljajući se oportunomu narodnjaštvu i dalmatinskomu autonomaštvu, talijanstvu i njemstvu, iredentizmu i fašizmu te srpstvu i jugoslavenstvu. ${ }^{33}$

Ipak, Ante Nižić izdvajao se od mnogih po tome što je uvijek uza se imao bilježnice, u koje je volio zapisivati sve i svašta. Tako se u Arhivu Provincijalata franjevaca trećoredaca na Ksaveru u Zagrebu nalazi kutija njegove ostavštine s pet takvih bilježnica. ${ }^{34}$ Posrijedi se rijetko susreće osobno bilježena svaštara čovjeka, koji je zapisivao sve svoje tekuće račune, vodio raznoraznu evidenciju, bilježio osobne susrete, razmišljanja i poteškoće, prenosio buduće planove, prispjele i poslane dopise, pisma itd. Nesumnjivo je bilo još Nižićevih bilježnica, a lako je moguće da ih još ima u trećoredskim samostanima. ${ }^{35}$ Nijedna za sada nema ni signaturne oznake ni posebnoga naslova, a na dvjema se nalazi naljepnica sa šturim podacima na koricama. ${ }^{36}$ Stoga smo Nižićevim bilježnicama, držeći se sadržajnoga i kronološkoga kriterija, dali sljedeće naslove:

1. Nadinska bilježnica o. Ante Nižića od 1904. do 1910. ${ }^{37}$

2. Lukoranska bilježnica o. Ante Nižića od 1911. do 1920.8

3. Rječnik glagoljskoga misala o. Ante Nižića ${ }^{39}$

$\overline{32}$ Župničku je službu u Lukoranu dobio zato što se pozvao na vlastite zdravstvene probleme koje je imao službujući na kopnu (L: 470).

33 PRODAN 1889; Isti 1895; Isti 1896; Isti 1900; Isti 1904; DIKLIĆ 2002: 119-142; Isti 2002: 119-142; Isti 2003; Isti 2005: 141-163; Isti 2012: 104-149.

34 Zahvaljujem franjevcima trećorecima glagoljašima, poglavito vlč. Kristijanu Kuharu i fra Branku Lovriću, što su mi dopustili ekscerpirati podatke iz Nižićevih bilježnica izvan samostanskoga prostora.

35 Svojevremeno mi je blagopokojni fra Petar Runje rekao da je neke Nižićeve bilježnice vidio u samostanu u Krku.

36 Knjiga 25 (Nadin), 1908-1910; Nižić, Zagreb, Ksaverska 79.

37 Riječ je o velikoj tvrdo ukoričenoj bilježnici od 300 ispisanih stranica u formatu $35 \times 21 \mathrm{~cm}$, kojoj na korici stoji da je Knjiga 25 (Nadin), 1908-1910, a njezine smo podatke u ovom članku citirali pod kraticom N.

38 Riječ je o velikoj tvrdo ukoričenoj bilježnici od čak 592 stranice u formatu 33 x $20 \mathrm{~cm}$, čije smo podatke u ovom članku citirali pod kraticom L.

39 Osim rječnika, koji je počeo stvarati 19. rujna 1920. u Lukoranu, posljednjih dana svoga župništva i dijecezanskoga svećeništva, a nastavio tijekom 1920. i 1921., kada je bio franjevački novak na Školjiću, bilježnica od 200 stranica u formatu 33 x 20 cm sadrži još skriptiranu Vajsovu 
4. Zaglavska i prvićka bilježnica o. Ante Nižića od 1928. do 1932.40

5. Ksaverska bilježnica o. Ante Nižića od 1933. do $1935 .{ }^{41}$

Među brojnim Nižićevim bilješkama izdvojili smo one o glagoljaštvu. Osim što se iz njih vidi da je glagoljaštvo silno pečatilo njegov svećenički život, one su prvorazredno svjedočanstvo kako se taj jezičnoliturgijski, kulturnopovijesni i nacionalnointegracijski fenomen reflektirao u prvim desetljećima 20. stoljeća.

\section{III.}

Ante Nižić, došavši u lipnju 1904. za župnika u Nadin (N: 57), propisno pastoralnoj i državnoj praksi najprije je popisao crkveni inventar (N: 57-62). Utvrdio je da se uredovni spisi vode u nadinskoj župi od 1870. (N: 61), da se u tekuće matične knjige rođenih, vjenčanih i umrlih zapisuju od 1826., 1825. odnosno 1803. godine (N: 61-62), da se čuvaju svi brojevi Dijecezanskoga lista te da postoje tri neliturgijske knjige, od kojih je jedna o kužnim bolestima, druga Pisme duhovne, a treća popularno medicinsko djelo $\operatorname{Vrač~(N:~62).~Od~liturgijskih~je~knjiga~}$ zatekao jedan 'sacrum convivum' latinski pozlaćen, a drugi stari glagoljački (N: 58), zatim dva misala, jedan latinski, a drugi glagoljački (N: 60), jedan šćavet, stari ritual, jedan polu novi, knjiga godova, librić kršćanskoga nauka (N: 60) te tri knjige za obrede velike nedilje i knjiga svete mise koje se pjevaju po hrvatskih župah (N: 60). Crkvenomu inventaru pridružit će kasnije mrtvački glagoljački misal, koji je za 5,20 kruna kupio 16. listopada 1905., potom novi glagoljački misal i glagolske knjižice mise, koje je za 50, odnosno za 2,80 kruna nabavio 11. svibnja 1906., odnosno 6. ožujka 1910. (N: 4, 10, 106), ali i Babićev Cvit razlika mirisa duhovnoga, Jelićeve Fontes Liturgiae glagolitae Romanae i Ivančićeve Povjestne crte o samostanskom III Redu sv. O. Franje po Dalmaciji, Kvarneru i Istri i poraba glagolice u istoj redodržavi $(\mathrm{N}: 62,106)$.

Od prethodnoga je župnika don Srećka Ivasovića naslijedio dokument $O$ porabi i pravu glagoljice u župskoj crkvi sv. Ante u Nadinu, koji je sastavljen 8. veljače 1903. u Nadinu, a potvrđen 17. lipnja iste godine u Zadru (N: 88). Na dokumentu su se križem ili vlastoručnim potpisom potpisali svjedoci kao starci župe Nadin,

staroslavensku te Maretićevu i Kušarovu hrvatsku gramatiku, neke natuknice iz Stullijeva i Miklošićeva rječnika, zanimljivosti iz franjevačke trećoredske povijesti i podatke iz prečanske povijesti, ali i evidencijske liste o prispjelim robnim artiklima i obiteljima u Lukoranu, koje su u ratnim i gladnim danima 1917. i 1918. dobile hranu. Njezine smo podatke pod kraticom R citirali u ovom članku.

40 Riječ je o meko uvezanoj bilježnici formata 24 x $19 \mathrm{~cm}$ od 186 stranica, ispisanih u vrijeme njegove kapelanske službe u Zaglavu i gvardijanstva u Prvić-Luci. Nema ni prve korice ni prvoga lista, a podatke smo joj u ovom članku citirali pod kraticom ZiP.

${ }^{41}$ Riječ je o tvrdo ukoričenoj bilježnici formata 22 x $14 \mathrm{~cm}$ od 400 stranica, ispisanih u vrijeme njegova službovanja u Zagrebu, a podatke smo joj u ovom članku citirali pod kraticom K. 
odnosno Marko Vrsaljko pok. Pere, Šime Brzoja pok. Tome, Grgo Jojić pok. Ive, Niko Ožaković pok. Ive, Krševan Vrsaljko pok. Jakova, Šime Vrsaljko pok. Mate, Roko Vicković pok. Marka, Tome Jojić pok. Ivana i Ive Margarin pok. Ante (N: 88). Nadinjani su došli do dozvole o uporabi i pravu glagoljice u svojoj župnoj crkvi sv. Ante jer su imali sve pozitivne odgovore na nadbiskupov upitnik, koji se naslanjao na odluku Svete Stolice iz 1899., kada je dopušteno staroslavensko bogoslužje u župnoj crkvi na temelju povijesne tradicije:

1. Je li bilo u ovoj župi glagoljačkih svećenika koji su pjevali sv. misu glagoljački jer nisu poznavali latinicu? - Bilo je od starine župnika glagoljačkih koji nisu znali latinicu.

2. Znate li Vi imenovati od tih župnika? - Sjećamo se mi stariji don Šime Mihića, don Mihovila Levačića i don Bože Petešića.

3. Jesu li predšastnici tih župnika Vama poznatih i oni pjevali glagoljački $i$ što ste čuli od vaših starih seljanaca u tom poslu? - I predšastnici gori spomenutih župnika pjevali su glagoljački kao don Jure Lazarić, don Luka Sikirić kako smo to čuli od naših starih i od ostalih staraca sela.

4. Znate li kazati kad se je pjevala sv. misa glagoljackki? - Uvijek od pamtivieka pjevala se je sv. misa glagoljački dok nije došao Zadranin don Jure Verichaza. Kašnje don Jure Verichaza u odsutnosti susljednih župnika posluživao je Nadin don Blaž Cvitanović iz Škabrnje te je on govorio misu glagoljački u našoj župskoj crkvi.

5. Znate li kad bi koji župnik pjevao sv. misu latinski, kako bi puk tada odgovarao? - Uvijek je puk odgovarao hrvatski pomješan sa staroslovenskim.

6. Znate li da je obstojalo u crkvi i župi glagoljačkih knjiga i pisama? -Bio je jedan misal glagoljački što se mi spominjemo koji se i sada nalazi u crkvi te knjiga godova (mrtvih), koja se još nalazi u crkvi, još obstoje tablice glagoljačke zvate, sacrum convivium ( $N$ : 88).

Nižić je zbog toga dokumenta odmah zatražio dozvolu iz Nadbiskupskoga ordinarijata da i on u nadinskoj crkvi može služiti misu na staroslavenskome jer je 6. prosinca 1900. u Nadbiskupskoj kuriji položio ispit iz staroslavenskoga jezika (N: 89). Iz Nadbiskupskoga mu je ordinarijata 13. rujna 1904. stigla dozvola pisana latinskim jezikom, koju je Nižić 15. lipnja 1910. izvjesio u crkvi sv. Ante na burnu stranu riznice na vječnu uspomenu (N: 89), s uputom da mora poraditi na petoj točki nadbiskupova upitnika jer nadinski puk mora u sv. misama naučiti odgovarati staroslavenski, bez primjese živućega hrvatskog jezika (N: 89). Gotovo da nije bilo glagoljaške župe koja nije kršila crkveni propis o jezičnoj čistoći u bogoslužju, a bilo je i župa u kojima se bogoslužje obavljao u kombinaciji staroslavenskoga s latinskim jezikom. ${ }^{42}$

42 DIKLIĆ 2002: 135. 
Važno je naglasiti da su župe Zadarske nadbiskupije preko upitnika, kakav je netom naveden iz Nadina, ponovno stjecale pravo na rimsko-slavenski obred. Lako ih je odobravao tadašnji zadarski nadbiskup Mate Dujam Dvornik (1901. - 1910.), koji je zbog naklonjenosti glagoljaštvu imao mnogo simpatizera, ali i protivnika. Tako je Nižić preko murvičkoga župnika Ive Milića u rujnu 1909. doznao da Seršić izvješćuje Rim o svim potankostima u pogledu nadbiskupa Dvornika, kojemu će sada biti određen coadiutor, a na tom polju radi se da bude imenovan dr. Gjivoje koji bi uredio biskupiju u malo godina, da bi nekoji popovi Hrvati htjeli učiniti na Rim memorandum proti nadbiskupu, ali to bi bilo nedično, jer se je opoštenio u pitanju glagolice i odatle mu izviru svi klipovi i da se je pokunjio u pogledu glagolice na želju Rima, bili bi ga učinili kardinalom (N: 42). Stoga ga je razljutio škabrnjski župnik don Mate Dražić, kada ga je krajem studenoga zamolio da mu sastavi Zapisnik za dokaz o glagolici u Škabrnji. Tada mu je, sastavivši Zapisnik i poklonivši mu usto knjigu Glagoljica u Pašmanu, rekao u lice da naš nadbiskup trpi radi glagolice, a mi župnici nismo kadri odazvati se odluci 31/8 1900. Br. 2815 (N: 242). Zapisnik je poslan Nadbiskupskom ordinarijatu 1. prosinca 1909. iz Nadina s pitanjima škabrnjskoga župnika i odgovorima škabrnjskih staraca:

1. Jeste li čuli od vaših starih da su uviek govorili misu glagoljački vaši župnici d. Miho Madjerić (1779-1780), d. Tome Magić (1780-1810), d. Stipe Torić (1810-1822), d. Jozo Marcelić (1822-1846)? - Odgovor: Čuli smo od naših starih, da su Madjerić, Torić, Magić govorili misu glagoljački kao i d. Jozo Marcelić.

2. Bili ste Vi znali kazati, koji je pop prvi kod vas uveo latinicu? - Odgovor: d. Blaž Blasul (1865-1874) koji nije poznavao glagolice, ali mu je puk isto odgovarao po staru glagoljačku pri njegovoj latinskoj misi, kao i danas, ali d. Blaž Cvitanović (1874-1884) naš župnik vazda je glagoljao, a i današnji dušobrižnik latina, jer mu je glagolicu bio zabranio pokojni nadbiskup Maupas.

3. Jeste li Vi vidili koji misal glagolski u vašoj crkvi? - Odgovor: Bilo ih je više, a i danas imamo u našoj crkvi glagolski misal tiskan u Rimu de propaganda fide MDCCXLI (1741.) po naredbi pape Urbana VIII. Glagolski nadpisi obstoje i danas na sudićima sv. ulja.

4. Bili ste Vi zakletvom potvrdili, da je istinito sve što ste izjavili na moje upite? - Odgovor: Bismo i zbilja se kunemo Bogom živim, da je cila istina što smo odgovorili.

Za razliku od većine ravnokotarskih župa, koje su tijekom prvoga desetljeća 20. stoljeća uglavnom obnovile svoj glagoljaški identitet, ugljanske su sve odreda bile latinaške. Na Ugljanu se jedino pravo glagoljalo, piše Nižić (L: 311), kod franjevaca trećoredaca glagoljaša na Školjiću. Stoga se dolaskom za lukoranskoga župnika na rodni otok silno uzradovao kada je u crkvenom inventaru zatekao novi glagolski Mrtvački misal i glagolske tablice (L: 585). Premda je u početku 
svakodnevno misio na latinskome i molio iz brevira latinskoga (L: 295), svoju je župu sv. Lovrinca polako pripremao na staroslavenštinu i hrvatski jezik. Jednom je zapisao sljedeće: Kao što se ne može odjednom urediti pohrvaćenje javnih ureda, isto tako se ne može svugdje u Dalmaciji uvesti glagoljaška misa i glagoljaške knjige (N: 135). Stoga je išao korak po korak. Najprije je s talijanskoga na materinski preveo Stanje duša župe Lukoran, države zadarske iz 1860. (L: 231), da bi početkom Prvoga svjetskog rata s ostalim ugljanskim župnicima bez suglasnosti Nadbiskupskoga ordinarijata naveliko počeo glagoljati u crkvi. Budući da je narod zbog toga bio veoma zadovoljan (str. 315), ugljansko je svećenstvo sve glasnije počelo tražiti obnovu rimskoga bogoslužja na staroslavenskom jeziku u svojim crkvama (L: 486).

Sam, pak, nadbiskup Pulišić strahovao je od posljedica obnove glagoljanja na Ugljanu, smatrajući da će se njegovi odjeci negativno osjetiti i u Rimu. S druge strane, Nižić je bio uvjeren da oko toga ne bi imao problema jer je novi papa Benedikt XV. (1914. - 1922.) blagonaklono gledao na staroslavensko bogoslužje, za razliku od prijašnjega Pija X. (1903. - 1914.), koji je, prema Nižićevu mišljenju, osobno bio neprijatelj glagolice (L: 315$) \cdot{ }^{43}$ Novi je papa oko staroslavenštine bio duhom Lava XIII. Rampolle, kako je rekao fra Stjepanu Ivančiću (1852. - 1925.) kada se 30. studenoga 1914. susreo s njime i od našega trećoreca sa zanimanjem primio knjigu La questione di S. Girolamo degli Schiavoni (L: 456). Stoga ne iznenađuje da je Sveta Stolica 15. siječnja 1915. u službenim Acta Apostolicae Sedis dala prevesti Dekret o ratnom molitvenom danu na osam jezika, pa je, osim na talijanskome, francuskome, engleskome, njemačkome, portugalskome, ruskome i poljskome, molitva prevedena i na staroslavenski jezik (L: 315). Doznavši iz novina da je Sveta Stolica službeno oglasila molitvu za mir i u staroslovenskom jeziku, u tom posvećenom liturgijskom jeziku, u miloj našoj starodrevnoj glagolici (L: 456. $)^{44}$, Nižić je 17. veljače 1915. od Nadbiskupskoga ordinarijata zatražio da se njegovoj glagolskoj župi Lukoranu, koja brižljivo čuva u svom arkivu glagolske spomenike, dostavi jedan primjerak molitve izdate od Sv. Oca pape Benedikta XV. jezikom starim hrvatskim i glagolskim pismenima (L: 456). Zanimljivo je da se pritom nije pozvao na Prodanovu Hrvatsku Krunu, čiji je bio vjerni pretplatnik, već na zagrebačke Novine. Vrlo brzo, 23. veljače 1915. tajnik Polonio poslao mu je iz Krka najkraći mogući odgovor: Takve molitve 'Acta Apostolicae sedis' ne imaju (L: 456). Ipak, u ožujku 1915. don Toma Mihatov pružio je Nižiću nadu da će se pitanje rimskoga bogoslužja na staroslavenskom jeziku s blagonaklonim papom doskora u Zadarskoj nadbiskupiji urediti jer je nadbiskup Pulišić osobni

\footnotetext{
43 Isto za nj piše i NOVAK 1948: 17.

44 H. M. Glagolica u Rimu. Hrvatska Kruna, br. 13, 10. veljače 1915.; Glagolica u Papinim Naredbama. Novine, br. 36, 13. veljače 1915.
} 
prijatelj Sv. Oca pape Benedikta XV., stoga da će nadbiskup prvim polaskom ad limina osobno urediti pitanje glagolice u našoj nadbiskupiji (L: 457).

Nakon što je Italija 23. svibnja 1915. navijestila rat Austro-Ugarskoj, računajući na tajni Londonski ugovor sa silama Antante, koji joj je, među ostalim, jamčio gotovo sav istočnojadranski prostor, samo četiri dana kasnije, 27. svibnja 1915. održan je sastanak ugljanskih svećenika okupljenih u Svećeničku zajednicu kod franjevaca trećoredaca glagoljaša na Školjiću. ${ }^{45}$ Ključna tema sastanka, koja se od Nadbiskupskoga ordinarijata tražila već punu godinu dana (L: 486), bio je zahtjev da se na temelju podastrtih dokaza o nekadašnjem glagoljanju omogući bogoslužje na staroslavenskom jeziku u crkvama po Ugljanu (L: 315). Prije sastanka, koji je protekao u sjeni talijanskoga ulaska u rat, fra Krsto Vukić rekao mu je kako je od dalmatinskoga talijanaša Antonija Cippica (1877. - 1935.) čuo da se na nedavnoj konferenciji u Rimu po prilici izreklo sljedeće: 'Ajte u Dalmaciju i prva stvar neka vam bude ova - ubijte popove i učitelje koji su uzdržitelji hrvatstva u talijanskoj Dalmaciji' (L: 457). Stoga je Nižić svoje zvanje za hrvatsku stvar smatrao itekako važnim, pa će doskora odbiti nadbiskupov prijedlog da se makne s Ugljana u Obrovac, držeći da je u osjetljivim vremenima potreban hrvatskomu narodu na rodnom otoku (L: 315 ).

Sastanak na Školjiću nije iznio željeni zaključak jer je nadbiskup Pulišić, premda je kao šibenski biskup 1905. glagoljao sv. misu na rodnom Olibu (L: 550), ponavljao da bi obnova glagoljanja na Ugljanu više škodila negoli bila od koristi (L: 315). Naime, predsjedniku Svećeničke zajednice don Šimi Segariću, župniku Sutomišćice i nekadašnjemu lukoranskomu ekskurentu, poslan je dekret kojim se ne dopušta pretresati na sastanku o predmetima koji prelaze djelokrug župnika, naime o glagolici (L: 315, 546). Na nadbiskupovu su zabranu glagoljanja na Ugljanu franjevci trećoreci glagoljaši odgovorili tako što su početkom 1916. odbili vršiti kapelansku službu u obližnjem Preku. ${ }^{46}$ Sam, pak, Nižić poslao je 29. lipnja 1915. pismo Nadbiskupskomu ordinarijatu, razočaran odlukom da se ne smije voditi niti javna rasprava o glagoljanju na Ugljanu (L: 551):

Smije li se hrvatski propovijedati u Lukoranu gdje puk jedino hrvatski govori, gdje su svi župnici govorili hrvatski, gdje su svi biskupi uviek govorili hrvatski pak bili i talijanci, gdje i svi talijanci iz Zadra govore hrvatski sa težakom, dočim je Lukoran uknjižen kao tobožnje selo talijansko u umišljenoj geografiji zadarskih talijana? Smije li i župnik glagolati u Lukoranu gdje puk glagola od vijeka, gdje su svi pravedni i poslušni župnici glagolali, gdje su svi biskupi štovali stari običaj, gdje je isti nadbiskup Pulišić u pastirskim pohodima 21. 6. 1911. i 5. 6. 1914. glagolskim jezikom obavio svoje molitve po priručniku tiskare Kurykte u Krku?

45 Više o svećeničkim zajednicama organiziranima po dekanatima u Dalmaciji vidi KAPITANOVIĆ 2002: 418-419.

46 U Preku je tada bio župnik budući zadarski nadbiskup Mate Garković, kojeg je nadbiskup početkom 1915. imenovao za ugljanskoga dekana, protivno volji ugljanskih svećenika (L: 311). 
Župniku Lukorana zabranjena je glagolica s jednoga uzroka, što u shematizmu nije župa proglašena glagolskom bez krivnje puka i župnika, koji je 9. 10. 1910. (br. 117) podastro dokaze, da se mirni posjed glagolice uknjiži u smislu odluke Svete Stolice. U istim prilikama glagolaju župnici Vinjerca, Savra i Bibinja, Obrovca, Sestrunja, Bibinja, Poličnika, Suovara, Kukljice, Benkovca, Popovića. Je li priličnije da se župnik izjednači puku komu niko ne prigovara niti sa strane crkvenih starešina, niti sa strane političkih faktora, da sluša glas Sv. Stolice koja zabranjuje miješanje glagolice i latinice, da se uniformira biskupu, ili da radi lažnih obzira prama nepozvanim faktorima, uzdrži jednu javnu neposlušnost prama Svetoj Stolici.

Kad bi bila zapitana Sveta Stolica u ovom slučaju, mislim da bi odgovorila da $i$ župnik Lukorana ima glagolati kako glagola i puk, jer je Sveta Stolica dala naputak dijecezanskim ordinarijatima (L. B. 1900. N 8), tim više da je taj Nadbiskupski ordinarijat trojakim činom potvrdio glagolicu u ovoj župi: 1) Što nije zabranio puku jer prelazi njegovu vlast; 2) Što je isti 21. 6. 1911. i 5. 6. 1914. obavio sa pukom glagolski propisane molitve; 3) Što je 21. 2. 1914. br. 339 izjavio da će biti glagolici u prilog; 4) Sada nije moguće obratiti se Svetoj Stolici radi ratnih prilika; 5) Što nije zabranio pismeno glagolicu pišućemu jer prelazi njegovu vlast.

Lukoran, 29. 6. 1915.

A.Nižić/potpis/.

Unatoč dozvolama i zabranama, Nižić je od 8. lipnja 1915. uvijek glagoljao u svojoj župi (L: 550). Njegovo će se razočarenje u vodstvo nadbiskupije sve više produbljivati jer je pitanje legitimiteta bogoslužja na staroslavenskom jeziku po njemu postalo pitanjem opstanka hrvatskoga naroda. Znao se zapitati kako je moguće da staroslavenska liturgija nema nadbiskupsku, a imala je papinsku dozvolu još u 13. stoljeću (L: 548), odnosno zar Nadbiskupski ordinarijat nije već 26. veljače 1843. izdao dozvolu o tome da se sve javne službe imadu obavljati glagolski (L: 550).

Na kraju Prvoga svjetskog rata, kada je nadbiskup izvjesio talijansku zastavu na katedralu i kada se sa svojim kolegama zarekao da će ubuduće samo glagoljati pa kud puklo, Nižić je donio popis župa Zadarske nadbiskupije u kojima se glagolja ili latina unatoč dozvolama ili zabranama, pa Vinjerac (glagola) iako nije tobože proglašen glagolski; Privlaka (Karavanić latina u glagolskoj župi gdje je bio glagoljaš Ivan Dorčić); Visočane (glagolska, a Heinrich latina); Ražanac (Meštrović latina); Novigrad (Eškinja glagola); Ervenik i Nunić (latinaju); Kistanje (latinaju); Obrovac (glagola, a nije proglašena tobože glagolska); $u$ Preku latinaju u glagolskoj župi; Vrgada (latina); Zapuntel (Seršić latina, zašto ne glagola), ${ }^{47}$ Savar i Birbinj (don Tome Šešelja glagola), Božava (Jadrošić lati-

47 Nakon što je 1915. don Šime Segarić postao počasnim kanonikom u crkvi sv. Šime u Zadru, Nižić mu je često pastoralno pomagao u njegovoj Sutomišćici (L: 486). 
na), Sutomišćica (latina), Lukoran (latina, 8. lipnja 1915. Nižić glagola), Ugljan (latina), Kukljica (glagola), Benkovac (glagola), Popović (glagola), Vrgada (latina), Sestrunj (glagola), Bibinje (glagola), Poličnik (glagola), Suovare (glagola) (L: 550). S kolikom se strašću u to doba pratilo tko je glagoljaš, a tko latinaš u svojim Zapisima svjedoči već spomenuti don Nikola Moscatello, koji kaže da je tada 'glagoljaš' bio titulus honoris za naše svećenike starije generacije, a 'latinaš' sinonim izroda i tuđinskoga sluge. ${ }^{48} \mathrm{Od} 1919$. ., kada je „reformistički“ krug nižega svećenstva u Hrvatskoj kroz Žuti pokret, među ostalim, tražio poništenje celibata i uvođenje narodnoga jezika u bogoslužje, sve koji su se protivili tomu i stajali na strani službene Crkve nazivalo se latinašima ${ }^{49}$

U lipnju 1918. Nižić je očekivao premještaj iz Lukorana (L: 430). No, unatoč tomu što je napustio rodni otok, odužilo se namještenje u drugu službu. ${ }^{50}$ Najprije mu je nadbiskup obećao katehetsku službu u Zadru, za koju se godinama pripremio recentnim knjigama i radnim planovima (L: 567-571). Potom mu je don Vice Selem savjetovao da preuzme Dračevac ili Bokanjac, odakle bi mogao pomagati u kolegijalnoj crkvi sv. Šime u Zadru (L: 430). U srpnju 1918. mislio je da će postati župnikom u Bokanjcu (L 430-431), čiji su stanovnici, prema kazivanju don Vice Selema, Vlasi najbliži Zadru, kojih će na najveće svetkovine biti 50 u crkvi (L: 431). Međutim, život mu je svaki dan bio sve teži. Naime, od ljeta 1918. živio je kao podstanar najprije u slobodnom, a od kraja 1918. u okupiranom Zadru, gdje ga je pratio krimen protivnika Italije koji javno iznosi prohrvatske i protutalijanske stavove (L: 448-449). ${ }^{51}$ Njegove su svete mise često završavale s Rajska Djevo Kraljice Hrvata i Do nebesa nek se ori isusovaca Petra Perice i Milana Smolke ${ }^{52}$, a zanimljivo je da o talijanskoj okupaciji i novonastalim problemima u njegovim bilježnicama nema niti jedne bilješke.

Nakon internacije u Zadru nadbiskup mu je dodijelio kapelansku službu u kolegijalnoj crkvi sv. Šimuna, gdje je u istoj službi bio trećoredac fra Kerubin Sišul. ${ }^{53}$ Vrlo brzo Nižić mu se pridružio kao bratu i glagoljašu, a doskora ga je u

\footnotetext{
48 MOSCATELLO 2014: 146-147.

SIŠUL 1963: 23.

51 Još prije rata javno je govorio da je Italija najpogibeljniji vanjski dušmanin države (L: 546), a i javno se osvrtao na pisanje protalijanskih novina Il Dalmata i Il Risogimento. Protiv prvih podignuo je tužbu zbog klevete napisane na račun njegove propovijedi iz lipnja 1912. u Ugljanu, ali je od daljnje tužbe morao odustati zbog nadbiskupova pritiska (L: 545). U ožujku 1914. napao ga je bezimeni Ugljančanin ponovno u Il Dalmata jer je tobože javno govorio protiv talijanskoga jezika, talijanske stranke, troglave i zadarske općine (L: 545). Nižić mu je u Hrvatskoj Kruni odgovorio da je samo izložio u duhu velikoga biskupa doktora Mahnića da slušaju Isusa i njegovu Crkvu, a uz to da ljube i svoj materinski hrvatski jezik (L: 545-546), ali i u novinama Il Risogimento, koje su ga, prema njegovu mišljenju, zbog staroslavenštine smatrale zločincem (L: 546, 549).

52 N: 126; SIŠUL 1963: 23.
} 
prijateljskim razgovorima upitao bi li ga prihvatila njegova redovnička zajednica jer je uvijek želio postati redovnikom. Kasnije fra Kerubin svjedoči da je između drugih poticala, zašto je odabrao naš Red, bila i glagolica kojom se mi služimo. ${ }^{54}$ U jesen 1920., nakon što je više od godine dana strpljivo čekao otpusnicu iz Nadbiskupskoga ordinarijata, stupio je u franjevce trećorece glagoljaše na Školjiću.

IV.

Svakomu tko je iz Preka poznati su mu franjevci trećoreci glagoljaši jer na obližnjem otočiću Školjiću (Galevcu) imaju samostan sv. Pavla Pustinjaka još od kasnoga srednjeg vijeka. Anti su Nižiću odmalena bili bliski. Kad mu je majka Kata 1909. umrla u Preku, na njezinu su pogrebu bila tri popa i dva redovnika sa Školjića te osobito cijenjeni fra Stjepan Ivančić (N: 212). Upravo je Ivančićev susret s Benediktom XV., kada je papa, među ostalim, udijelio blagoslov trećemu samostanskom redu i staroslavenskomu jeziku, najpoticajnije djelovao na Nižića oko angažmana u obnovi staroslavenskoga bogoslužja na Ugljanu. Također je utjecao na to da je Nižić od 1915. gotovo uvijek misio na staroslavenskom jeziku. S trećorecima je prijateljevao, osobito s fra Kerubinom Sišulom (1892. - 1981.), koji ga je upoznao dok je bio gimnazijalac i sa svojim odgojiteljima često posjećivao Nižića u Lukoranu, a on bi ih tada uz tamburicu i domoljubne pjesme podvorio baškotom, sirom i vinom..$^{55}$

U rujnu 1920. pop glagoljaš Ante Nižić pristupio je Trećemu samostanskom redu sv. Franje (ZiP: 195). Novicijat je obavio, ne promijenivši ime, u samostanu sv. Pavla Pustinjaka na Školjiću. Uz redovite novačke obveze, bavio se izradom staroslavenskoga misalskog rječnika, učenjem glagoljske paleografije i staroslavenske gramatike (Abecedarium Paleoslavicum in usum glagolitarum Josipa Vajsa iz 1909.) te hrvatskoga pravopisa i gramatike (Nauka o pravopisu jezika hrvackoga ili srpskoga (fonetičkom i etimologijskom) Marćela Kušara iz 1889. i Gramatika i stilistika hrvatskoga ili srpskoga književnog jezika Tomislava Maretića iz 1899.), čitanjem Ivančićevih radova iz franjevačke trećoredske povijesti, proučavanjem povijesti rodnoga Preka te uređivanjem samostanskih knjižnica na Školjiću (Galevcu) i Krku. ${ }^{56}$

S radom na Rječniku glagoljskoga misala iz 1893. započeo je 19. rujna 1920., kada je odlučio svakoj riječi zabilježiti stranicu misala. K riječi staviti prevod latinski (uz hrvatski). Vas misal do riječi proći, jer sramota je ne znati svojih stvari. Bilježiti redni broj, dan, mjesec i godinu rada (R: 1). Tako je 26. rujna

\footnotetext{
SIŠUL 1963: 23.

54 Na istome mjestu.

55 L: 371, 571; SIŠUL 1963: 23.

56 Usp. R: passim.
} 
1920. zapisao da je Matica Hrvatska 1895. izdala rječnik hrvatsko slavenski za slovenske svoje članove (R: IV), a on ga je dobio 1906. preko Šaše, urednika Istine, te se zapitao zašto hrvatski biskupi ne bi mogli izdati glagolski riječnik misala za glagolaše (R: IV). Do kraja 1920. pročitao je sav Parčićev misal (R: V) te je, stvarajući polako azbučni rječnik, opetovao cijeli misal glagolski u Zagrebu do 15. 10. 1925. (R: IV). Zanimljiva je bilješka od 20. veljače 1921., kada je naveo u čemu je tajna napretka u glagoljici: Vajs svaki dan pročita sv. misu prije nego li iđe na oltar; don Jakov Parać svaki dan moli brevir glagolski i tako neprestana svagdanja vježba čini majstora u predmetu; nulla dies sine linea (R: IV). Tri je dana ranije zapisao da bi Rječnik glagolskog misala trebalo izdati što prije preko staroslovenske akademije u Krku i da je projekt isplativ kada bi išla za svakužupu po dva primjerka, za župnika i za župu (R: 1). Potom je naveo da bi uz rječnik trebalo napisati i izdati Poviest izdanja glagolskog misala, Kako ćeš postati vješt u glagolici i Malu slovnicu, koju bi Jakov Parać mogao sastaviti prema Vajsu (R: 1). Sam, pak, rječnik, ako ga ne bi izdala Staroslavenska akademija, mogla bi njegova Redodržava glagolska III. Reda sv. Frane (R: 1). O svemu tome trebalo bi se savjetovati s fra Stjepanom Ivančićem i tražiti odobrenje hrvatskih biskupa (R: 1). Nažalost, sve su zamisli ostale neostvarene, pa i sam rječnik koji je ostao u rukopisu.

Upravo je o Staroslavenskoj akademiji ostavio vrijedne podatke (L: 322-323, 353). U godini borbe za staroslavensko bogoslužje na Ugljanu, 9. rujna 1915. poslao je zahtjev za učlanjenjem (L: 323), plativši jednokratno 100 kruna kako bi uz redovito članstvo postao i Akademijim podupirateljem (L: 580). Zapisao je poimence sve Akademijine podupiratelje i članove iz Dalmacije (L: 322) ${ }^{57}$ Popis podupiratelja i redovitih članova ponovit će 15. ožujka 1922., od kojih je

7 Članovima podupirateljima bili su: dr. Antun Alfirević (vjeroučitelj u Splitu, pristupio 30. X. 1905.), Ivan Butković (profesor bogoslovlja u Zadru, pristupio 30. X. 1912.), Ante Nižić (župnik u Lukoranu, pristupio 14. IX. 1915.), Knjižnica reda sv. Franje konventualaca u Šibeniku (12. XII. 1903.) i dr. Josip Marčelić (dubrovački biskup, 2. VII. 1903.), a redovitim članovima: don Silvestar Bonačić (natpop u Visu, 18. IV. 1914.), don Ante Banić (natpop u Ninu, 6. IV. 1910.), dr. Josip Bervaldi (Split, 31. XII. 1903.), upraviteljstvo župne crkve u Biogradu na moru (28. X. 1909.), don Tome Bilić (Betina), msgr. Frane Bulić (umirovljeni gimnazijski ravnatelj, 10. II. 1903.), Pacifik Car (župnik u Kolanu na Pagu, 21. IV. 1908.), Đuro Dorotić (župnik u Vrbanju, 27. IV. 1908.), pop Jozo Grabovac (Sinj, 27. IV. 1908.), Luka Grgić (kanonik u Splitu, 11. IX. 1903.), pop Ivan Grgin (Dusina pokraj Vrgorca, 31. XII. 1903.), don Frane Ivanišević (umirovljeni župnik u Krilu, 11. IX. 1903.), Leopold pl. Ivanišević (kanonik u Splitu, 11. IX. 1903.), Marko Ivanišević (župnik u Podgori, 11. IX. 1903.), Srećko Ivasović (Filip Jakov, 28. X. 1909.), pop Mijo Kalebić (župnik u Dugopolju, 31. XII. 1903.), Ivan Kasandrić (prof. bogoslovlja u Zadru, 30. III. 1915.), pop Marko Kalogjera (župnik u Splitu, 31. XII. 1903.), Ivan Lubin (kanonik i župnik u Kaštel Štafiliću, 11. IX. 1903.), Toma Mihatov (dušobrižnik u Pašmanu, 30. XII. 1906.), Biskupski ordinarijat u Šibeniku, don Roko Počina (prof. glagoljice u Zadru), o. Petar Plepel (župnik Suhi Dolac - Perković, 31. XII. 1903.), Provincijalat franjevaca trećoredaca u Zadru, dr. Vinko Pulišić (Zadar, 7. II. 1914.), samostan Male braće na Pašmanu (13. II. 1912.), samostan Male braće na otoku kod Korčule (24. II. 1914.), trećoredski samostan Preko kod 
najviše iz Splitske biskupije (25), potom iz Zadarske nadbiskupije (15) i Šibenske biskupije (4), a najmanje ih je bilo iz Hvarske (3) i Dubrovačke biskupije (1) (L: 353).

Prva redovnička služba fra Ante Nižića bila je kapelanska u crkvi sv. Franje Ksaverskoga u Zagrebu (ZiP: 156). S ondašnjim je provincijalom fra Bonom Zecom (1868. - 1954.) bio prvi trećoredac sa službom u Zagrebu. ${ }^{58}$ Dolasku franjevaca trećoredaca u Zagreb kumovala je talijanska okupacija hrvatskoga dijela Jadrana, kojom je trećorecima u Zadru i Martinšćici ograničen, a u Velom Lošinju onemogućen boravak i rad u samostanima. U Zagreb su stigli preporukom krčkoga biskupa Antuna Mahnića, koji ih je prije svoje smrti navodno hrabrio da pođu u Zagreb, gdje možete ondje s glagoljicom u svetim obredima donijeti velike koristi Crkvi i narodu našemu, a prihvatio ih je gornjogradski župnik Svetozar Ritig (1873. - 1961.), veliki ljubitelj i promotor staroslavenštine, pod čijom se jurisdikcijom nalazila crkva sv. Franje Ksaverskoga, uz koju će trećoreci početi podizati istoimeni samostan nakon što im je u studenome 1923. darovana crkva i spadajuće zemljište. ${ }^{59}$ Očito je da je preporuka Nižićevu dolasku u Zagreb bila njegova strast za bogoslužje na staroslavenskom jeziku.

Kratko, od 21. kolovoza do 30. studenoga 1926., fra Ante Nižić obnašao je gvardijansku dužnost još uvijek nedovršenoga samostana na Ksaveru (ZiP: 140-143). Tada je 22. listopada 1926. s položaja upravitelja crkve sv. Franje Ksaverskoga uputio pismo gradskomu poglavarstvu, tražeći materijalnu pomoć za trećorece jer je gradsko poglavarstvo 2. lipnja 1923. najtoplije priopćilo cjelokupnom građanstvu i svim privrednim institucijama glagoljaše sa otoka Krka, istjerane od Talijana iz Lošinja, za što obilnije milodare, bilo u novcu, bilo u robi, za samostan kod sv. Franje Ksavera u Zagrebu. ${ }^{60}$ Nadalje piše da se ondje od 1923. ori slava Bogu glagoljicom hrvatske recenzije, u obnovljenoj znamenitoj crkvi, zaslugom Hrvatske žene u Zagrebu.

Zadra (1906.), pop Mate Škarica (umirovljeni župnik u Kaštel Starom, 31. XII. 1903.), pop Mijo Tomasović (kurat u Kučićima kraj Omiša, 31. XII. 1903.), Grgo Topić (kurat u Svinišću, 31. XII. 1903.), don Niko Trnta Tabulov (profesor bogoslovlja u Zadru, 7. VI. 1911.), don Stanislav Vidović pok. Marina (kurat u Vinišću kod Trogira, 16. II. 1905.), Ivan Vuletin (župnik u Kaštel Novom), Zbor duhovne mladeži u Zadru (28. VI. 1905.), Ivan Zanki (župnik u Kotišini kod Makarske, 11. IX. 1903.), pop Ante Žarnić (župnik u Malom Prologu p. Metković, 31. XII. 1903.) trećoredski samostan u Krku (29. I. 1903), trećoredski samostan sv. Mandaljene u Portu (29. I. 1903), trećoredski samostan u Glavotoku (18. VII. 1903.) i konventualski samostan na Cresu (17. I. 1904.), Ivan Brajević (trgovac iz Splita, 14. IV. 1914.), Pavao Matovac (župnik u Aržanu, 8. V. 1914.), prof. Jakov Parać (23. I. 1915.), Stjepan Kaštelan (župnik u Gatima, 30. III. 1915.), Matej Mihanović (župnik u Srijanima, 1912.), pop Mijo Rubić (župnik u Poljicima kod Krivodola, 31. XII. 1903.).

BADURINA 1998: 17.

Isto: 17-18.

Pismo je pronađeno među stranicama njegova Rječnika. 
Zanimljiva su Nižićeva razmišljanja iz srpnja 1928. o mogućem dolasku franjevaca trećoredaca u Rab. Njih je iz Prvić-Luke, gdje je od 1927. do 1930. bio gvardijan samostana Bl. Djevice Marije od Milosti, uputio fra Kerubinu Sišulu u Preko (ZiP: 43-44). Trećorecima je rapska općina najviše radi glagolice ponudila mogućnost otvaranja samostana u samom Rabu (ZiP: 44), a Nižić je uz svu dobru volju bio protiv toga zbog pomanjkanja personala u zajednici, savjetujući da trećoredske samostane treba eventualno osnivati u većim gradovima, a ne u kupališnim mjestima poput Raba jer redovnici po kupalištima veoma malim plodom mogu se pohvaliti (ZiP: 43-45). Mora se jačati Zagreb, isticao je Nižić, jer je on sada franjevačka središnjica gdje se imademo pripraviti za velike zadaće, što nas čekaju u hrvatskom narodu (ZiP: 44-45). Osim toga, savjetuje Nižić, Crkvi ne treba još jedan samostan na Rabu jer je u Kamporu samostan zadarskih franjevaca opservanata, koji bi od krčkoga biskupa Josipa Srebrnića (1923. - 1966.) mogli tražiti dozvolu za bogoslužje na staroslavenskom jeziku, ako već vjernička zajednica otoka Raba želi duhovno rasti u glagoljaškom duhu (ZiP: 43-44). Nižiću se taj prijedlog učinio dosta zgodnim jer je katoličkomu svećenstvu objavom latiničnoga misala Rimski misal slověnskim jezikom prěsv. g. $n$. Urbana papi VIII povelěnjem izdan 9. ožujka 1927. u Rimu olakšan pristup bogoslužju na staroslavenskom jeziku, a i doznao je da u Žrnovu na Korčuli odnedavno službuje slovenski svećenik koji prije nije niti vidio staroslavenskoga misala, a sada lijepo glagola na zadovoljstvo naroda i crkvene oblasti, bez vike i buke (ZiP: 44).

Za gvardijanstva u Prvić-Luci, koji je tada bio pred gašenjem, Nižić je uvodio reda u samostanu $i c r k v i{ }^{61}$, nailazeći na velike otpore nekih do tada privilegiranih mještana, koje je nazivao vikači (ZiP: 1-15, 52-53). Čak je zbog njih dobio ukore od svojih nadređenih (ZiP: 160). U želji za premještajem, u kolovozu 1930. ponovno se vratio za samostanskoga kapelana u Zagreb (ZiP: 174), čemu je najviše pripomogla kupnja cjelokupne knjižnice pokojnoga biskupa Antuna Mahnića, koju je provincijalna uprava s novim ormarima platila 15400 dinara i smjestila je na donjem podu do kapele (ZiP: 128; K: 320). Još od novicijatskih dana fra Ante Nižić isticao se kao revan ljubitelj i reditelj samostanskih knjižnica, a ne samo jednom isticao je da redovnik u svemu treba da bude uređen, pak i u knjižnici. Uređena knjižnica zrcalo je redovnika. Uredimo se dakle u svemu $i$ tada redovnik biće omen i cognomen jer govorili su monasi da je samostan bez knjižnice kao tvrđa bez oružja (R: 49; K: 320). Mahnićeve, pak, knjige čine osnovicu današnje samostanske knjižnice na Ksaveru u Zagrebu. Ukupno ih je bilo 2467, a Nižić ih je katalogizirao i složio na police između 8. studenoga 1930. i 12. veljače 1931. (K: 320). O ksaverskoj je knjižnici još zapisao da bi trebala nama svima, iza svete crkve, biti najmilijom dvoranom, gdje možemo razgovarati sa velikanima, čija su imena neumrla (K: 320). U knjižnicu je stavio malu

$\overline{{ }_{61}}$ U rujnu 1929. pribavio je samostanu Prilog novog glagolskog misala za 100 dinara (ZiP: 76). 
sliku biskupa Mahnića (K: 320), koji je 14. prosinca 1920. umro kao prognanik u Zagrebu, a kosti su mu do 4. studenoga 1929. najprije počivale na Mirogoju, odakle su prenesene na Ksaver i položene ispod bočnoga oltara Bezgrešnoga Začeća u ksaverskoj crkvi (K: 321). ${ }^{62}$

Biskupova su načela, pogotovo ljubav pram Svetoj Stolici i ratobornost na obranu prava hrvatskoga naroda, iako je bio Slovenac, bila životno nadahnuće fra Anti Nižiću i njegovoj subraći iz ksaverskoga samostana (K: 321). Nadahnuće je bio i angažiranim slovenskim katolicima, koji su prilikom tradicionalnih hodočašća Majci Božjoj Bistričkoj redovito svraćali na Ksaver odati počast svom velikanu nad njegovim grobom. Tako je 12. rujna 1933., prilikom hodočašća 700 slovenskih vjernika, narodni poslanik Lojze Pavlič u ksaverskoj crkvi istaknuo da će on svim silama nastojati da naši trećoredci glagoljaši svoje djelovanje prenesu i u Sloveniju (K: 400). Na to je novi provincijal o. Pijo Dujmović (1870 - 1935), ocrtavši u nekoliko riječi veličinu biskupa Mahnića, zahvalio na akciji Slovenaca da glagoljaši prošire svoje djelovanje među Slovencima, apelirajući na sve njih da kod kuće pripreme sve što je potrebno da bude omogućen njihov rad i staroslovenski jezik odjekivati će u slovenskim crkvama, jer do sada smo mi katolici, zaključio je, malo cijenili veličinu povlastice koju imadu u službi Božjoj naši oo. trećoredci (K: 400).

Ne znamo točne razloge neodlaska franjevaca trećoredaca glagoljaša u Sloveniju, kojoj su trebali donijeli staroslavensko bogoslužje u njezine crkve. Uvođenje staroslavenskoga bogoslužja sigurno ne bi spriječila ni Rimska kurija, ni Biskupska konferencija, ni mjesni biskupi ukoliko bi vjernici određene crkve jednodušno to htjeli. ${ }^{63}$ Zašto onda staroslavensko bogoslužje nije zaživjelo diljem Jugoslavije? Povijest uči da se staroslavenska riječ slabo primala u svim sredinama koje nisu imale glagoljaške tradicije. Nije pripomogao ni latinični staroslavenski misal iz 1927., za koji su se desetljećima zalagali mnogi iz neglagoljaških sredina, a ne bi pripomogao ni Nižićev praktični staroslavensko-latinski rječnik da je bio izdan.

Bilješke o. Ante Nižića o glagoljaštvu pružaju nam uvid u dva svijeta. Prvi je onaj osobni, autorov, Nižićev, kojim nam otkriva svoje stavove, razmišljanja, osjećaje i postupke. Njemu je glagoljaštvo životni ideal, preko kojega je duhovno, kulturno, prosvjetno i politički najlakše dopirao do ljudi. Stoga se u svim svojim službujućim mjestima zalagao za bogoslužje na staroslavenskom jeziku. To se nastojanje u pastoralnoj službi na rodnom Ugljanu, puno intenzivnije negoli u župama na kopnu, pretvorilo u borbu za hrvatski nacionalni izraz, koju

62 RADIĆ 1940: 236-237.

63 MOSCATELLO 2014: 147. 
bi, između ostaloga, poticao širenjem hrvatskoga tiska i kupovanjem hrvatskih knjiga te stalnim držanjem hrvatske trobojnice na župnoj crkvi. Stoga se u svojim bilješkama gdjekad znao okomiti na svećenika, ako bi na glagoljaškoj župi pokazao nemar prema staroslavenštini, a osobito mu je smetalo oprezno držanje nadbiskupa Vicka Pulišića prema staroslavenskom jeziku, suprotstavljajući mu uvijek u takvim prilikama lokalnu glagoljašku tradiciju, svjedočanstva iz crkvene povijesti i blagonaklonjene crkvene autoritete, poput pape Inocenta IV., Leona XIII. i Benedikta XV. U svemu je tome uvijek bio na crti Prodanova dalmatinskoga pravaštva i Mahnićeva katoličkoga pokreta.

Idealističko držanje prema glagoljici, tj. rimsko-slavenskom obredu i staroslavenskom jeziku, u 47. ga je godini života odvelo u trećoredsku samostansku zajednicu, gdje je odmah postao jednim od najustrajnijih zagovaratelja redovničke formacije u glagoljaškom duhu. Odlasku u trećorece svakako je kumovala talijanska okupacija rodnoga zavičaja, s kojom je u javnosti, poput mnogih svećenika, prokazan kao hrvatski nacionalist. Do 1935., kada je preko Atlantika, možda iz nekoga razočarenja, ali svakako s novim izazovom otišao u Ameriku, najduže na službi bio je u Zagrebu, gdje su franjevci trećoreci glagoljaši upravo zbog žive staroslavenske riječi u bogoslužju i obveze da će ju čuvati u Zagrebu crkvu i okolno zemljište na Ksaveru dobili u trajno vlasništvo. Nižić je staroslavenštinu uvijek stavljao ispred svih drugih oblika duhovnosti. U tome je bio jedan od rijetkih. Pomalo naivno, doznavši 9. veljače 1932. da bi mogao postati gvardijanom u Zagrebu, sastavio je program svoga gvardijanstva još iste večeri (ZiP: 46-47). Među 15 točaka našla se i ona da bi se uz objed trebali čitati directorium de officio i staroslavenska misa kako bi se klerici koji su se školovali u Zagrebu vježbali u staroslovenštini kojom se moramo odlikovati (ZiP: 47). No, već je sutradan doznao da od gvardijanske službe neće biti ništa. Iz njegovih se bilježaka vidi kako se uopće nije obazirao na raznorazne manifestacije, koje su sa staroslavenskim izvodile nakon 1918., kada su se javljali mnogi zagovaratelji bezuvjetnoga uvođenja staroslavenskoga jezika u rimokatoličko bogoslužje, a da u svom djelovanju i službi nikada nisu upotrijebili niti jedne staroslavenske riječi.

Silno zapisivanje u velike i male bilježnice o. Ante Nižića, uz osobni, pružilo je i drugi pogled, onaj na svijet toga vremena. Podaci koji se pojavljuju u njegovim bilješkama nerijetko dopunjuju spoznaje ne samo o lokalnoj sredini i njegovoj svećeničkoj zajednici, već i općenito o hrvatskom društvu prvih desetljeća 20. stoljeća. Neke od njih bacile su potpuno novo svjetlo na određene događaje, pojave i ličnosti, poput pogleda u različite politike prema glagoljaštvu i staroslavenštini, uloge nadbiskupa Dvornika u revitalizaciji glagoljaških župa u Zadarskoj nadbiskupiji, rezerviranosti nadbiskupa Pulišića zbog bojazni od talijanaša i Italije prema staroslavenskom bogoslužju, jačanju hrvatskoga nacionalnog duha na Ugljanu i u drugim kulturno i jezično graničnim područjima ulaskom Italije u 
rat protiv Austro-Ugarske, sinkronijskih pogleda na latinaške i glagoljaške župe Zadarske nadbiskupije u 20. stoljeću, poimenične podrške Staroslavenskoj akademiji u Dalmaciji, pokušaja izrade praktičnoga staroslavensko-latinskog rječnika na osnovi Parčićeva misala, pozivnice franjevcima trećorecima glagoljašima da s bogoslužjem na staroslavenskom jeziku dođu u Sloveniju itd.

Bilješke o. Ante Nižića svjedočanstvo su nepokolebljivosti glagoljaškoga duha hrvatskih svećenika s vjekovnih glagoljaških područja, koji su se, unatoč pokušaju instrumentalizacije staroslavenskoga bogoslužja za prve Jugoslavije, uspjeli održati u vjernosti Rimu. Njihov nepokolebljiv duh traje i nakon koncilskoga izjednačenja latinskoga i crkvenoslavenskoga u bogoslužju s narodnim jezicima.

\section{Bibliografija}

BADURINA, Anđelko. 1998. Trećoredci na Ksaveru. U Svetište svetoga Franje Ksaverskoga u Zagrebu: povodom 75. obljetnice dolaska franjevaca trećoredaca glagoljaša u Zagreb, ur. Anđelko Badurina, 17-23. Zagreb: Provincijalat franjevaca trećoredaca glagoljaša.

BANAC, Ivo. 2013. Hrvati i Crkva. Kratka povijest hrvatskoga katoličanstva u modernosti. Zagreb-Sarajevo: Profil, Svjetlo riječi.

BOLONIĆ, Mihovil. 1968. Krčki seoski kaptol - pioniri i nosioci liturgijskog života. Bogoslovska smotra 38/2: 263-284.

BRATULIĆ, Josip. 2015. Josip Vajs - učenik i učitelj hrvatskih glagoljaša. U Hrvatsko glagoljaštvo u europskom okružju, ur. Vesna Badurina Stipčević, Sandra Požar i Franjo Velčić, 17-35. Zagreb: Staroslavenski institut.

BULIĆ, Frane. 1952. Iz „Zapamćenja“. Slovo 1: 35-45.

DIKLIĆ, Marjan. 2002. Politički program i borba za glagoljicu don Ive Prodana. U Hrvatski katolički pokret: Zbornik radova s Međunarodnoga znanstvenog skupa održanog u Zagrebu i Krku od 29. do 31. ožujka 2001., ur. Zlatko Matijević, 119-142. Zagreb: Kršćanska sadašnjost.

DIKLIĆ, Marjan. 2003. Don Ivo Prodan: političko djelovanje i parlamentarni rad. Zadar: Matica hrvatska.

DIKLIĆ, Marjan. 2005. Dalmatinsko pravaštvo i rješavanje hrvatskoga nacionalnog i državnog pitanja. Zadarska smotra 52 (2003 [i. e.] 2005)/1-3: 141-163.

DIKLIĆ, Marjan. 2012. Don Ivo Prodan kao svećenik, političar i zastupnik zadarskoga kraja. Zadarska smotra 61/3-4: 104-149.

Glagolica u Papinim Naredbama. Novine, br. 36, 13. veljače 1915.

GREGOV, Nikola. 2010. „Nižić, Ante“. U Hrvatski franjevački biografski leksikon. Ur. Franjo Emanuel Hoško, Pejo Ćošković, Vicko Kapitanović. Zagreb: Leksikografski zavod Miroslav Krleža, Vijeće franjevačkih zajednica Hrvatske i Bosne i Hercegovine.

H. M. Glagolica u Rimu. Hrvatska Kruna, br. 13, 10. veljače 1915. 
KAPITANOVIĆ, Vicko. Hrvatski katolički pokret od „Riječkih novina“ do kraja Prvoga svjetskog rata. U Hrvatski katolički pokret: Zbornik radova s Međunarodnoga znanstvenog skupa održanog u Zagrebu i Krku od 29. do 31. ožujka 2001., ur. Zlatko Matijević, 409-436. Zagreb: Kršćanska sadašnjost.

KOLAR, Mira. 2002. Hrvatska poljodjelska banka i hrvatsko selo (1901.-1946.). U Hrvatski katolički pokret: Zbornik radova s Međunarodnoga znanstvenog skupa održanog u Zagrebu i Krku od 29. do 31. ožujka 2001., ur. Zlatko Matijević, 195-209. Zagreb: Kršćanska sadašnjost.

KOVAČIĆ, Slavko. 2004. Splitsko-makarski biskup Filip Franjo Nakić (1889.-1910.) prema glagoljanju i glagoljašima. U Glagoljica i hrvatski glagolizam, ur. Marija-Ana Dürrigl, Milan Mihaljević, Franjo Velčić, 89-111. Zagreb-Krk: Staroslavenski institut, Krčka biskupija.

KRIŠTO, Jure. 2004. Hrvatski katolički pokret (1903.-1944.). Zagreb: Glas koncila, Hrvatski institut za povijest.

JAKULJ, Ivan. 2013. Međunarodni ugovori Svete Stolice i Crne Gore: povijesno-pravni vid. Crkva u svijetu 28/2: 236-261.

JELIĆ, Lucas. 1906. Fontes historici liturgiae glagolito-Romanae a XIII ad XIX saeculum. (Veglae), Jadrensis, Labacensis: (Kurykta), E. Vitaliani, Officina typographica catholica.

JURIŠIĆ, Pavo. 2011. Posljednji pobornici glagoljice. Kačić 41-43 (2009 [i. e.] 2011): 1113-1130.

MATAUŠIĆ, Juraj Mirko. Susret Crkve s civilnim društvom u XIX. stoljeću. U Hrvatski katolički pokret: Zbornik radova s Međunarodnoga znanstvenog skupa održanog u Zagrebu i Krku od 29. do 31. ožujka 2001., ur. Zlatko Matijević, 33-55. Zagreb: Kršćanska sadašnjost.

MATIĆ, Zdravko. 2008. Hrvatski katolički seniorat i njegove karakteristike. Radovi Zavoda za hrvatsku povijest 40: 211-230.

MOSCATELLO, Nikola. 2014. „,Uspomene“ u svjetlu dokumenata: doprinos povijesti katolicizma u Jugoslaviji (1922.-1946.). Bilješkama popratio Stipe Kljajić. Rim-Split: Papinski hrvatski zavod svetog Jeronima, Crkva u svijetu.

NOVAK, Viktor. 1948. Magnum crimen. Pola vijeka klerikalizma u Hrvatskoj. Zagreb: Tisak Nakladnog zavoda Hrvatske.

PRODAN, Ivo. 1889. La secchia rapita ili Obračun između Srba i Hrvata. U Zadru: Brzotiskom Kat. hrv. tisk.

PRODAN, Ivo. 1895. Uspomene I. Naš program. Zadar: U nagradjenoj tiskarnici Vitaliani i sinovi.

PRODAN, Ivo. 1896. Uspomene VIII. Borba s talijanašima. Zadar: U nagradjenoj tiskarnici Vitaliani.

PRODAN, Ivo. 1900. Uspomene X. Borba za glagolicu. I. dio. Poviest glagolice i nje izvori. Zadar: U nagradjenoj tiskarnici Vitaliani.

PRODAN, Ivo. 1904. Je li glagolica pravo svih Hrvata?. U Zadru: Slovim Katoličke hrvatske tiskarne. 
RADIĆ, Ignacije. 1940. Doktor Antun Mahnić, biskup krčki. Slavonska Požega: „Dobra štampa".

RELJANOVIĆ, Marijo. 2001. Enciklika Grande munus i pitanje obnove glagoljaštva u Dalmaciji. Radovi Zavoda za povijesne znanosti HAZU u Zadru 43: 355-374.

SOLDO, Ante Josip. 1990. Antun Dragutin Parčić i njegov glagoljski misal. Slovo 39-40 (1989-1990): 167-186.

[SIŠUL], Kerubin. 1963. In memoriam o. Ante Nižić. Vjesnik Provincije franjevaca trećoredaca 1/1: 23-24.

ŠKUNCA, Stanko Josip. 2014. Prošlost Crkve u Istri. Pazin: Državni arhiv u Pazinu.

ŠULJAK, Andrija. 1994. Biskup Josip Juraj Strossmayer i ćirilometodsko-glagoljska baština. Diacovensia 2/1: 275-294.

TANDARIĆ, Josip. 1973. Novi staroslavenski misal (Prigodom izdanja Rimskog misala slověnskym jazykem, v Olomuci 1972.). Slovo 23: 205-210.

TANDARIĆ, Josip. 1982. Oživljavanje hrvatske redakcije staroslavenskog jezika u bogoslužju. Kačić 14: 333-340.

VELČIĆ, Franjo. 2015. Talijansko-hrvatska polemika o glagoljici i vatikanska diplomacija krajem 19. i početkom 20. stoljeća. U Hrvatsko glagoljaštvo u europskom okružju, ur. Vesna Badurina Stipčević, Sandra Požar i Franjo Velčić, 75-100. Zagreb: Staroslavenski institut.

VUKŠIĆ, Tomo. 2002. Katoličanstvo i pravoslavlje na prijelazu iz XIX. u XX. stoljeće. U Hrvatski katolički pokret: Zbornik radova s Međunarodnoga znanstvenog skupa održanog u Zagrebu i Krku od 29. do 31. ožujka 2001., ur. Zlatko Matijević, 77-100. Zagreb: Kršćanska sadašnjost.

\section{Glagolitic Culture during the First Decades of the $20^{\text {th }}$ Century in Ante Nižić's Entries}

Entries of Father Ante Nižić (1873-1963), Glagolitic priest of the Archdiocese of Zadar and, from 1920, a third order Glagolitic Franciscan monk, are based on five of his notebooks, in which he wrote down all sorts of things: his account of current expenses, various records, personal encounters, his thoughts and troubles, future plans, received and sent writings, letters and so on. These notes were created occasionally from 1904 when he began his ministry in the village of Nadin until 1935 when he went to the USA.

The paper has focused on the entries on Glagolitic culture during Ante Nižić's time. For him, the Glagolitism was a life ideal, through which he was able to most easily reach people spiritually, culturally, educationally and politically. Thus he advocated the liturgy in Old Church Slavonic language wherever he performed his ministry. This pastoral effort on his native island of Ugljan, much more intensely than in parishes on the Dalmatian mainland, turned into a struggle 
for Croatian national expression, which he encouraged by, among other things, spreading the Croatian press, buying the Croatian books and constant exposure of the Croatian national three-coloured flag on the parish church. By doing all this, he was faithfully on the line with Prodan's ideology of Dalmatian Party of Rights and Mahnić's Croatian Catholic Movement. Thus he sometimes used to attack priests if they showed negligence towards Old Slavonic culture, and he was particularly annoyed by Archbishop Vicko Pulišić's cautious attitude towards the Old Church Slavonic language, confronting him, in such instances, with the local Glagolitic tradition, testimonies from the Church's history and benevolent ecclesiastical authorities such as Popes Innocent IV, Leo XIII and Benedict XV.

His idealistic stance towards the Glagolitic script, i. e. the Roman-Slavic rite and Old Church Slavonic language made him enter a third order Franciscan monastic community at the age of 47 , where he immediately became one of the most persistent advocates of monastic formation in Glagolitic spirit. His joining the Tertiary Franciscans was certainly helped by Italian occupation of his native land after which he was, same as many priests, denounced as a Croatian nationalist. Until 1935, his longest ministry was in Zagreb, where the Glagolitic Tertiary Franciscans were given the permanent ownership of the church and surrounding land at Ksaver due to the maintenance of the live Old Slavonic word in liturgy and their commitment to its preservation. Nižić had always put the Old Slavonic culture ahead of all other forms of spirituality. His entries show that he completely ignored various manifestations that were played out with the Old Church Slavonic language after 1918 when there appeared many advocates of unconditional introduction of the Old Slavonic language in the Roman Catholic liturgy, but who never used any Old Slavonic word in their activities and ministries.

Nižić's entries have illuminated Archbishop Dvornik's role in revitalization of Glagolitic parishes in the Archdiocese of Zadar, shown the strength of Croatian national spirit on the island of Ugljan after Italy had entered the war against Austria-Hungary, allowed a synchronistic view on Latin-language and Old Slavoniclanguage parishes of the Archdiocese of Zadar in the $20^{\text {th }}$ century, provided a list of names of the Old Slavonic Academy supporters from Dalmatia, highlighted the attempt to create a practical Old Slavonic-Latin dictionary based on the Parčić Missal and failed arrival of the Glagolitic Tertiary Franciscans in the town of Rab and in Slovenia.

Father Ante Nižić's entries are testimonies of a staunch Glagolitic spirit of the Croatian priests from the old Glagolitic areas which, despite an attempt at instrumentalization of the Old Slavonic liturgy during the first Yugoslavia, managed to maintain their fidelity to Rome. Their steadfast spirit persists even after the 
conciliar decision to make Latin and Old Church Slavonic languages equal with national languages in liturgy.

Keywords: Ante Nižić, history of Glagolitism, history of the Archdiocese of Zadar, history of the 3rd Order Franciscans, the Glagolitic Missal Dictionary

Ključne riječi: Ante Nižić, povijest glagoljaštva, povijest Zadarske nadbiskupije, povijest franjevaca trećoredaca glagoljaša, Rječnik glagoljskog misala

Ivan Botica

Staroslavenski institut

HR-10000 Zagreb, Demetrova 11 ibotica@stin.hr 


\section{FILOZOFSKI FAKULTET SVEUČILIŠTA U ZAGREBU \\ ZAVOD ZA HRVATSKU POVIJEST \\ INSTITUTE OF CROATIAN HISTORY \\ INSTITUT FÜR KROATISCHE GESCHICHTE}
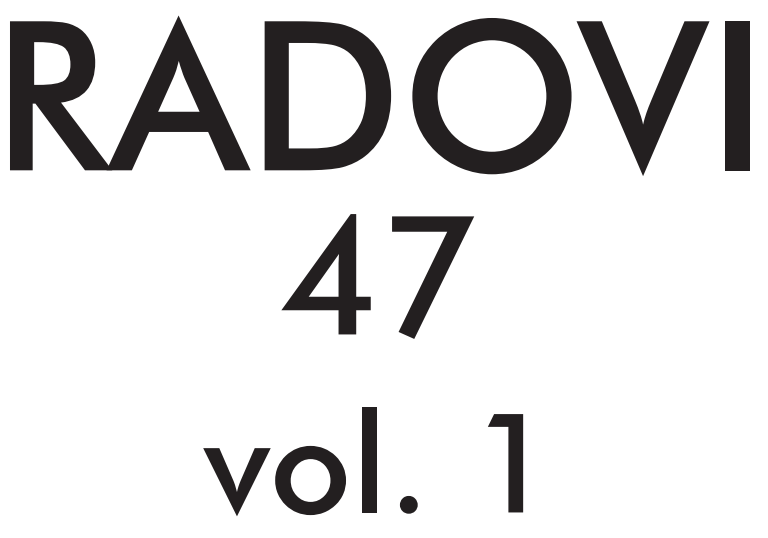

ZAVOD ZA HRVATSKU POVIJEST

FILOZOFSKOGA FAKULTETA SVEUČILIŠTA U ZAGREBU

\section{PF press \\ ZAGREB 2015.}




\title{
RADOVI ZAVODA ZA HRVATSKU POVIJEST FILOZOFSKOGA FAKULTETA SVEUČILIŠTA U ZAGREBU
}

\author{
Knjiga 47, vol. 1
}

\author{
Izdavač / Publisher \\ Zavod za hrvatsku povijest \\ Filozofskoga fakulteta Sveučilišta u Zagrebu \\ FF-press \\ Za izdavača / For Publisher \\ Vlatko Previšić \\ Glavni urednik / Editor-in-Chief \\ Hrvoje Gračanin \\ Izvršna urednica / Executive Editor \\ Inga Vilogorac Brčić \\ Uredništvo / Editorial Board
}

Bruna Kuntić-Makvić (stara povijest/ancient history), Zrinka Nikolić Jakus (srednji vijek/ medieval history), Hrvoje Petrić (rani novi vijek/early modern history), Željko Holjevac (moderna povijest/modern history), Tvrtko Jakovina (suvremena povijest/contemporary history),

Silvija Pisk (mikrohistorija i zavičajna povijest/microhistory and local history),

Zrinka Blažević (teorija i metodologija povijesti/theory and methodology of history)

Međunarodno uredničko vijeće / International Editorial Council

Denis Alimov (Sankt Peterburg), Živko Andrijašević (Nikšić), Csaba Békés (Budapest), Rajko Bratož (Ljubljana), Snježana Buzov (Columbus, Ohio), Svetlozar Eldarov (Sofija), Toni Filiposki (Skopje), Aleksandar Fotić (Beograd), Vladan Gavrilović (Novi Sad), Alojz Ivanišević (Wien),

Egidio Ivetić (Padova), Husnija Kamberović (Sarajevo), Karl Kaser (Graz),

Irina Ognyanova (Sofija), Géza Pálffy (Budapest), Ioan-Aurel Pop (Cluj),

Nade Proeva (Skopje), Alexios Savvides (Kalamata), Vlada Stanković (Beograd), Ludwig Steindorff (Kiel), Peter Štih (Ljubljana)

Izvršna urednica za tuzemnu i inozemnu razmjenu / Executive Editor for Publications Exchange Kristina Milković

Tajnik uredništva / Editorial Board Assistant

Dejan Zadro

Adresa uredništva/Editorial Board address

Zavod za hrvatsku povijest, Filozofski fakultet Zagreb, Ivana Lučića 3, HR-10 000, Zagreb

Tel. ++385 (0)1 6120 150, 6120 158, faks ++385 (0)1 6156879

Časopis izlazi jedanput godišnje / The Journal is published once a year

Časopis je u digitalnom obliku dostupan na / The Journal in digital form is accessible at Portal znanstvenih časopisa Republike Hrvatske „Hrčak“ http://hrcak.srce.hr/radovi-zhp

Financijska potpora za tisak časopisa / The Journal is published with the support by

Ministarstvo znanosti, obrazovanja i športa Republike Hrvatske

Časopis je indeksiran u sljedećim bazama / The Journal is indexed in the following databases:

Directory of Open Access Journals, EBSCO, SCOPUS, ERIH PLUS 
Naslovna stranica

Iva Mandić

Grafičko oblikovanje i računalni slog

Marko Maraković

Lektura

Samanta Paronić

Tisak

Web2tisak, Zagreb

Naklada

250 primjeraka

Časopis je u digitalnom obliku dostupan na Portalu znanstvenih časopisa Republike Hrvatske ,Hrčak“ http://hrcak.srce.hr/radovi-zhp

The Journal is accessible in digital form at the Hrcak - Portal of scientific journals of Croatia http://hrcak.srce.hr/radovi-zhp 


\section{RADOVI 47}

\section{vol. 1}

ZaVoda za hrVAtSku poviJest FILOZOFskoga fakulteta SVeuČILIŠTA u Zagrebu 


\title{
Tematski blok / Themed issue
}

\section{TREĆOREDSKA GLAGOLJAŠKA TRADICIJA U EUROPSKOM KONTEKSTU TERTIARY GLAGOLITIC TRADITION IN EUROPEAN CONTEXT}

\author{
Radovi međunarodnoga znanstvenog skupa \\ održanoga 27. i 28. IX. 2013. na Hrvatskom katoličkom sveučilištu u Zagrebu \\ u organizaciji \\ Provincije franjevaca trećoredaca glagoljaša u Zagrebu, Hrvatskoga katoličkog \\ sveučilišta u Zagrebu, Filozofskoga fakulteta Sveučilišta u Zagrebu - Odsjek za \\ povijest, Filozofskoga fakulteta Sveučilišta u Splitu - Odsjek za povijest, Instituta \\ za povijest umjetnosti u Zagrebu i Staroslavenskoga instituta u Zagrebu \\ Proceedings of the International Scientific Conference \\ held on 27th and 28th September 2013 at the Catholic University of Croatia in Zagreb \\ and organized by \\ the Province of the Glagolitic Friars of the Third Order Regular, Catholic University \\ of Croatia in Zagreb, Faculty of Humanities and Social Sciences of the University \\ of Zagreb - Department of History, Faculty of Humanities and Social Sciences of \\ the University of Split - Department of History, Institute of Art History, \\ and Old Church Slavonic Institute
}

Gosti urednici / Guest editors

\author{
Ivan BOTICA \\ Tomislav GALOVIĆ \\ Kristijan KUHAR
}

